\title{
SARS-CoV-2 and Viral Sepsis: Immune Dysfunction and Implications in Kidney Failure
}

\author{
Alessandra Stasi ${ }^{1}{ }^{\circledR}$, Giuseppe Castellano ${ }^{2}$, Elena Ranieri ${ }^{3}{ }^{\circledR}$, Barbara Infante ${ }^{2}$, \\ Giovanni Stallone ${ }^{2}$, Loreto Gesualdo ${ }^{1}$ and Giuseppe Stefano Netti ${ }^{3, *}$ \\ 1 Nephrology, Dialysis and Transplantation Unit, Department of Emergency and Organ Transplantation, \\ University of Bari, 70124 Bari, Italy; alessandra.stasi@uniba.it (A.S.); loreto.gesualdo@uniba.it (L.G.) \\ 2 Nephrology, Dialysis and Transplantation Unit, Department of Medical and Surgical Sciences, \\ University of Foggia, Viale Luigi Pinto, 71122 Foggia, Italy; giuseppe.castellano@unifg.it (G.C.); \\ barbarinf@libero.it (B.I.); giovanni.stallone@unifg.it (G.S.) \\ 3 Clinical Pathology, Department of Surgical and Medical Sciences, University of Foggia, Viale Luigi Pinto, \\ 71122 Foggia, Italy; elena.ranieri@unifg.it \\ * Correspondence: giuseppestefano.netti@unifg.it; Tel.: +39-088-173-2619; Fax: +39-088-173-6001
}

Received: 22 October 2020; Accepted: 8 December 2020; Published: 15 December 2020

\begin{abstract}
Severe acute respiratory syndrome coronavirus 2 (SARS-CoV-2), the causal agent of coronavirus disease 2019 (COVID-19), first emerged in Wuhan, China. The clinical manifestations of patients infected with COVID-19 include fever, cough, and dyspnea, up to acute respiratory distress syndrome (ARDS) and acute cardiac injury. Thus, a lot of severe patients had to be admitted to intensive care units (ICU). The pathogenic mechanisms of SARS-CoV-2 infection are mediated by the binding of SARS-CoV-2 spikes to the human angiotensin-converting enzyme 2 (ACE-2) receptor. The overexpression of human ACE-2 is associated with the disease severity in SARS-CoV-2 infection, demonstrating that viral entry into cells is a pivotal step. Although the lung is the organ that is most commonly affected by SARS-CoV-2 infection, acute kidney injury (AKI), heart dysfunction and abdominal pain are the most commonly reported co-morbidities of COVID-19. The occurrence of AKI in COVID-19 patients might be explained by several mechanisms that include viral cytopathic effects in renal cells and the host hyperinflammatory response. In addition, kidney dysfunction could exacerbate the inflammatory response started in the lungs and might cause further renal impairment and multi-organ failure. Mounting recent evidence supports the involvement of cardiovascular complications and endothelial dysfunction in COVID-19 syndrome, in addition to respiratory disease. To date, there is no vaccine, and no specific antiviral medicine has been shown to be effective in preventing or treating COVID-19. The removal of pro-inflammatory cytokines and the shutdown of the cytokine storm could ameliorate the clinical outcome in severe COVID-19 cases. Therefore, several interventions that inhibit viral replication and the systemic inflammatory response could modulate the severity of the renal dysfunction and increase the probability of a favorable outcome.
\end{abstract}

Keywords: SARS-CoV-2; acute kidney injury; sepsis

\section{Introduction}

The new respiratory infectious disease, coronavirus disease 2019 (COVID-19), first originated in Wuhan, China, and was triggered by a new strain of coronavirus, called severe acute respiratory syndrome coronavirus 2 (SARS-CoV-2). As of November 2020, it has infected 57.531.154 individuals and caused more than 1.370 .606 deaths globally [1]. The clinical spectrum of COVID-19 infections ranges from mild symptoms to severe forms. It has been reported that $80 \%$ of cases are mild; $10 \%$ are severe, developing severe diseases including pneumonia and dyspnea [2]; $2 \%$ are critical, and develop 
respiratory failure, septic shock and multi-organ failure requiring intensive care treatment; and, in about $2 \%$ of the overall reported cases, the virus is lethal [2].

The most common clinical manifestations of the infection include fever, cough, myalgia or fatigue, dyspnea, sputum production, and the presence of bilateral infiltrates on chest imaging [2]. In addition, some COVID-19 patients developed acute respiratory distress syndrome (ARDS) [3]. Others have reported acute cardiac injury, acute kidney injury (AKI) [4], and shock, and many of them had to be admitted to the intensive care unit (ICU) [5].

The pathogenic mechanisms of SARS-CoV-2 infection are derived from the comparative genomic analysis of the other two analogous coronaviruses, SARS coronavirus (SARS-CoV) and MERS coronavirus (MERS-CoV) [2]. The genomic analysis revealed that SARS-CoV-2 had a sequence identity of $79 \%$ with SARS-CoV and $50 \%$ with MERS-CoV, and presented a strong similarity to the pathogenic mechanism of SARS-CoV infection $[2,6,7]$.

Indeed, the new coronavirus, like SARS-CoV, mediated the host cell infection by the binding of SARS-CoV-2 spikes to human angiotensin-converting enzyme 2 (ACE-2) receptors [8].

The ACE- 2 is expressed in various human organs due to its pivotal role in a variety of pathological and physiological conditions [9]. Certainly, the expression of ACE-2 on the surface membrane of alveolar cells triggers pulmonary injury, and it is commonly accepted that the lung is the primary target organ of SARS-CoV-2 infection.

The occurrence of AKI has often developed in patients infected by SARS-CoV-2. The pathogenesis of AKI in COVID-19 has a multifactorial etiology [10]. First of all, the expression of ACE-2 has been described in several organs, including the kidney [11]. Several studies reported the expression of ACE-2 in podocytes and proximal straight tubular cells, suggesting that SARS-CoV-2 could directly infect the human kidney and induce cytopathic effects in renal cells, contributing to AKI and the spread of the virus in the body [9,12-14].

Another important finding was that COVID-19 patients with more severe clinical manifestations had higher serum concentrations of pro-inflammatory mediators and immune cells dysfunction that enhanced cytokine storm, leading to renal dysfunction, as observed in sepsis disease [15-17]. Therefore, AKI may have an inflammatory etiology mediated by an exacerbated immune response.

In addition, kidney dysfunction could hamper the host's inflammatory response starting at the lung, inducing further renal impairment and the severe damage of the other organs, such as the lungs and heart [18]. In this way, the kidney could lead to a self-amplifying inflammatory response that rapidly increases both the local and systemic damage.

Emerging evidence supports support the detrimental role of endothelial dysfunction and coagulopathy in predisposing to the development of renal dysfunction in COVID-19 syndrome.

Currently, the therapeutic approach is based on supportive care treatment, since vaccines or target therapies are not yet available [2]. Concerning blood purification treatment, it is considered an option for severe cytokine release syndrome (CRS) and to restore immune homeostasis in COVID-19 patients.

Since AKI is a frequent complication in critically ill patients, understanding the principal mechanism of renal impairment could help us to discover new effective therapeutic strategies that are capable of counteracting kidney injury and improving the clinical outcome of COVID-19 patients [2].

\section{SARS-CoV-2: Mechanism of Cellular Infection}

Coronaviruses are single-stranded RNA viruses belonging to the Coronaviridae family. Based on their genomic structure, they are classified into four genera: $\alpha, \beta, \gamma$, and $\delta$. Both $\alpha$ and $\beta$ coronaviruses tend to infect mammals, and they include SARS-CoV, MERS-CoV, and SARS-CoV-2 [19].

The life cycle of all viruses depend on host cells, and involve five stages-attachment, penetration, biosynthesis, maturation, and release-which are necessary for their replication and metabolic processes. The attachment is the first step in which the virus interacts with specific host receptors and penetrates host cells through endocytosis or membrane fusion. After entering the host cells, the viral RNA is 
released in the host cytoplasm, and it is used to synthetize viral proteins. The final stage consists of the final maturation and virus release [20].

As is well known, Coronaviruses present four structural proteins: spike (S), membrane (M), envelop (E), and nucleocapsid (N) [21]. Spike protein is a transmembrane glycoprotein, formed by two functional subunits. The S1 subunit is necessary for the binding of the host cell receptor, and S2 is important for the penetration stage. As for SARS-CoV infection, human ACE-2 (hACE-2) was identified as the functional receptor that is responsible for the binding of SARS-CoV-2 to host cells [22]. After the host's exposure to SARS-CoV-2, the viral entry is dependent on the interaction between the $\mathrm{NH}$-terminal peptidase domain of ACE-2 at the surface of the host cells and the viral S1 domain [23]. Then, the S1 domain is cleaved by host furin-like protease, inducing conformational changes of the S2 site that facilitate the fusion of the viral and host cellular membrane. Moreover, the low $\mathrm{pH}$ and $\mathrm{pH}$-dependent endosomal cysteine protease are also required to mediate the virus penetration in the host cells [24]. After entering into the cytoplasm, the viral RNA is translated in its replicase and structural proteins through the host transcriptional machinery, generating new virions and extending the site of infection [24].

The ACE-2 is an important regulator of the renin-angiotensin system (RAS) that has a crucial role in the balance between fluid and salts, and in the homeostasis of blood pressure. In addition, RAS controls local cellular responses, physiological developmental processes and organ function [25]. In RAS, ACE-2 cleaves Angiotensin (Ang) II, which mediates vasoconstriction pro-inflammatory and pro-fibrotic process, and converts it into Ang (1-7), which has opposite effects, promoting vasodilation and anti-proliferative pathways [25]. Then, ACE-2 regulates the physiological and pathological mechanisms of different organs [25].

Several studies have underlined the involvement of ACE-2 in the pathological progression of several diseases, and it may also be implicated in the susceptibility to SARS-CoV-2 infection and the clinical outcome of COVID-19 patients [26]. Indeed, the ACE-2 has been specifically reported in type II pneumocytes, and functions as a receptor for SARS-CoV-2, suggesting that the lungs are the primary target for the virus attack [22]. Moreover, it has been found in various organs, including the kidneys, demonstrating that SARS-CoV-2 could directly infect other organs in addition to the lungs [27].

Recently, Shang et al. deeply described the cell entry mechanism of SARS-CoV-2, which explained its potency and evasiveness, and the differences between SARS-CoV-2 and SARS-CoV infection [22]. First of all, the SARS-CoV-2 receptor binding domain (RBD) showed a significantly higher hACE-2 binding affinity than the SARS-CoV RBD [22]. In addition, its RBD was mostly in the lying-down state [28,29]; this ineffective state in hACE2 binding was a strategy to maintain RBD that is less accessible, in order to evade immune surveillance. Interestingly, SARS-CoV-2 applied a second strategy to assure its high infectivity through host protease activation [22]. Given that there is an extra genetic region unique to SAR-CoV-2 that translates to a furin-like cleavage site in the S protein [30], the authors showed that furin pre-activation was necessary for the virus entry into several hACE2-expressing cell lines [22]. Moreover, they observed that transmembrane serine protease 2 (TMPRSS2) and lysosomal cathepsins were also required to process the SARS-CoV-2 S protein, and facilitated host cell entry [22].

Since the RBD of SARS-CoV-2 is less accessible in the lying-down state, the efficacy of vaccines based on neutralizing antibodies for RBD may be limited; this approach may be hardly successful. Considering that SARS-CoV-2 uses several proteases for cell entry, the use of inhibitor mixtures against multiple protease activators and siRNA approaches could counteract the infectivity of the virus and achieve a satisfactory outcome.

\section{Kidney Dysfunction in SARS-CoV-2 Infection and the Risk for Progression to Chronic Kidney Disease}

The lungs are the primary organs affected by SARS-CoV-2 infection; however, recent evidence has demonstrated that AKI, cardiac damage and abdominal pain are the most common co-morbidities observed in people severely affected by the COVID-19 disease [31]. 
The exact incidence of AKI in COVID-19 disease is still not fully clear [32]. Huang et al. reported that $7 \%$ of SARS-CoV-2 infected patients developed AKI, and $23 \%$ of critically ill patients experienced AKI [33]. In another study conducted on 99 patients affected by COVID-19 disease, seven cases developed various levels of renal damage, and three of them were diagnosed with AKI [34]. In addition, in a multicenter study, Guan et al. reported that the AKI incidence rate was only $0.5 \%$ [35].

In a recent study conducted on 59 SARS-CoV-2 patients, $\mathrm{Li}$ et al. demonstrated that a massive albuminuria occurred in $34 \%$ of subjects on the first days of the admission, and $63 \%$ of them developed proteinuria during their hospitalization [36]. In addition, blood urea nitrogen (BUN) was increased in $27 \%$ overall, and-more interestingly - two thirds of the deaths were correlated with both elevated BUN and serum creatinine (SCr) over $200 \mu \mathrm{mol} / \mathrm{L}$ [36]. Recently, Cheng et al. showed that $44 \%$ of hospitalized patients with COVID-19 presented proteinuria and hematuria, and $26.7 \%$ overall had hematuria on admission. Moreover, the increasing rates of BUN and $\mathrm{SCr}$ were $14.1 \%$ and $15.5 \%$, respectively, and the incidence of AKI was 3.2\% [37]. Finally, this study reported that $50 \%$ of the patients who developed AKI, died [37]. Therefore, it appears that the incidence rate of AKI in SARS-CoV-2 infection is lower than in SARS and MERS disease.

However, Yang et al. recently reported that, amongst critically ill hospitalized patients with COVID-19 in Wuhan, China, 29\% of them were affected by AKI [38]. Accordingly, Diao et al. [13] demonstrated in a retrospective study that $27.06 \%$ of patients had AKI, and that older patients had a higher risk to develop AKI [13]. Therefore, there is a high incidence of AKI in patients with severe and critical conditions.

Moreover, in a retrospective study conducted on 163 critically ill patients who recovered from SARS-CoV-2 infection, only one subject presented AKI; instead, 28 patients out of 113 critically ill patients who did not survive developed AKI during the course of their hospitalization [39]. Clearly, AKI plays an important role in the prognosis of critically ill SARS-CoV-2 patients, and it is associated to a high incidence of death [31].

Clearly, in order to understand the incidence of AKI in COVID-19 disease, it is is important to consider the demographic risk factors and clinical conditions of patients at admission and during hospitalization [10]. Recent data proposed several demographic parameters-such as male sex, older age, diabetes mellitus, hypertension, cardiovascular disease, congestive heart failure, high body mass index, chronic kidney disease (CKD), genetic risk factors, immunosuppression, and smoking history - that could induce or increase the incidence and progression of AKI [10,40-42]. Lin et al. performed the first systematic analysis of the COVID-19 risk factors on 79 research articles, and showed that patients with advanced age were more vulnerable to the development of AKI, probably due to weakened immune system function and the physiological aging of organs [43]. Moreover, Shastri et al. observed that male patients had a lower capacity in SARS-CoV-2 clearance after infection compared to female patients, underlying the gender disparity in the disease's severity [44]. Moreover, the impact of high-risk behaviors like smoking and alcohol consumption could make male patients more susceptible to AKI in COVID-19 disease [43]. Moreover, certain genetic traits might increase susceptibility to the development of AKI in the course of SARS-CoV-2 infection [10]. Several reports have revealed histological signs of collapsing glomerulopathy in African American patients with COVID-19 infection [45-47]. As is well known, the Apolipoprotein L1 (APOL1) risk allele is more common in African people, and confers a high risk of renal injury to this ethnic group [48]. Therefore, it is plausible that collapsing glomerulopathy following SARS-CoV-2 infection may be associated with APOL1 kidney risk alleles [10]. Otherwise limited data suggest that polymorphisms in the ACE-2 gene might influence the ability of the virus to infect cells [10]. The mortality rate and incidence of AKI vary considerably between countries and different health care systems [10]. Data from several studies in China showed that AKI is less common among COVID-19 patients compared to patients in the USA and Europe $[33,35,49,50]$. Indeed, Chinese patients had fewer comorbidities, and were admitted to hospital with less severe respiratory disease. To our knowledge, there are no relevant results that correlated the different hospital settings and the risk of AKI $[33,35,49,50]$. Furthermore, the clinical conditions 
of patients at admission—such as the severity of COVID-19, dehydration, hypoxemia, lymphopenia, leukocytosis, increased markers of inflammation, rhabdomyolysis and medication exposure with ACE inhibitors and/or angiotensin-receptor blockers (ARBs), statins, nonsteroidal anti-inflammatory drugs and other potentially nephrotoxic drugs—may induce renal damage [10]. Among hospitalized COVID-19 patients, those exposed to mechanical ventilation, nephrotoxins like antibiotics or contrast media, and vasopressors as part of their clinical care, had a high incidence of AKI and experienced worse outcomes [10]. Therefore, as reported in the consensus report of the 25th Acute Disease Quality Initiative (ADQI) Workgroup [10], clinical risk stratification is necessary in order to prevent the occurrence of AKI in COVID-19 disease, and to improve the treatment strategies in order to assure the better prognosis of critically ill patients.

Since several clinical and experimental studies have shown that the severity of AKI is strongly associated with the development of fibrosis and the progression to chronic kidney disease (CKD) [51,52], it is reasonable to expect the same scenario in an increased load of patients with COVID-19-associated AKI. Recently, Chan et al. published a clinical study report about the persistence of kidney dysfunction in survivors of COVID-19-associated AKI [53]. This study analyzed 3993 hospitalized patients with COVID-19 in New York City, and showed that a third of the patients with AKI had not recovered to baseline kidney function at the time of discharge [53]. The low recovery rate is expected to be due to the severity of the AKI in these patients. Indeed, several studies in many patients with COVID-19 have found remarkable signs of damage in tubular cells and podocytes associated with proteinuria, hematuria or leukocyturia, and microthrombi [14]. Similar results were also found in a Chinese cohort study, with less than half of the patients recovering their kidney function [41]. The delayed consequences associated to AKI and the risk of CKD progression remain to be elucidated. From a pathophysiological point of view, the detrimental events that characterize COVID-19-associated AKI—such as endothelial dysfunction, hypoxic insult, immunological dysregulation, inflammatory processes, tubular damage and the impairment of parenchymal repair-could trigger the transition process to CKD. Therefore, further investigations are required on the clinical follow-up of post-AKI patients in a COVID-19 setting.

\section{Pathogenesis of AKI in COVID-19 Disease: Possible Role of ACE-2 and Direct Viral Infection}

Our current knowledge on the pathogenesis of SARS-CoV-2-induced AKI is largely presumptive, and comes from previous studies in MERS and SARS-CoV diseases [32]. Renal dysfunction could be the result of both direct coronavirus infection and the cytokine storm due to abnormal host immune response [32] (Figure 1).

As has previously been underlined, ACE-2 is the main binding site for SARS-CoV-2, and it is not only expressed in lung tissue, but rather has been reported in other organs, including the kidney [54]. In particular, ACE-2 is mainly detected in proximal tubules, on the brush border apical membrane, where it colocalizes with ACE and maintains the homeostasis of the RAS as a negative regulator [26]. It is also present in podocytes, mesangial cells, the parietal epithelium of Bowman's capsule, and the collecting ducts [11,55-57].

The expression level of ACE- 2 in the kidneys is crucial in the pathogenesis and progression of renal dysfunction in several diseases [58]. Accumulating evidence has shown that the decrease of ACE-2 expression and activity was implicated in different models of both acute and chronic kidney diseases, and it was associated with the loss of RAS homeostasis and worsened pathological changes in renal parenchyma $[58,59]$.

SARS-CoV-2 may induce renal impairment by different mechanisms, including direct viral infection by ACE-2 binding. It is plausible that the higher renal tropism of SARS-CoV-2, due to the increase affinity of the S1 domain for ACE-2, could allow it to direct the cytopathic effects of the virus and the local disruption of RAS homeostasis [4] (Figure 1). 


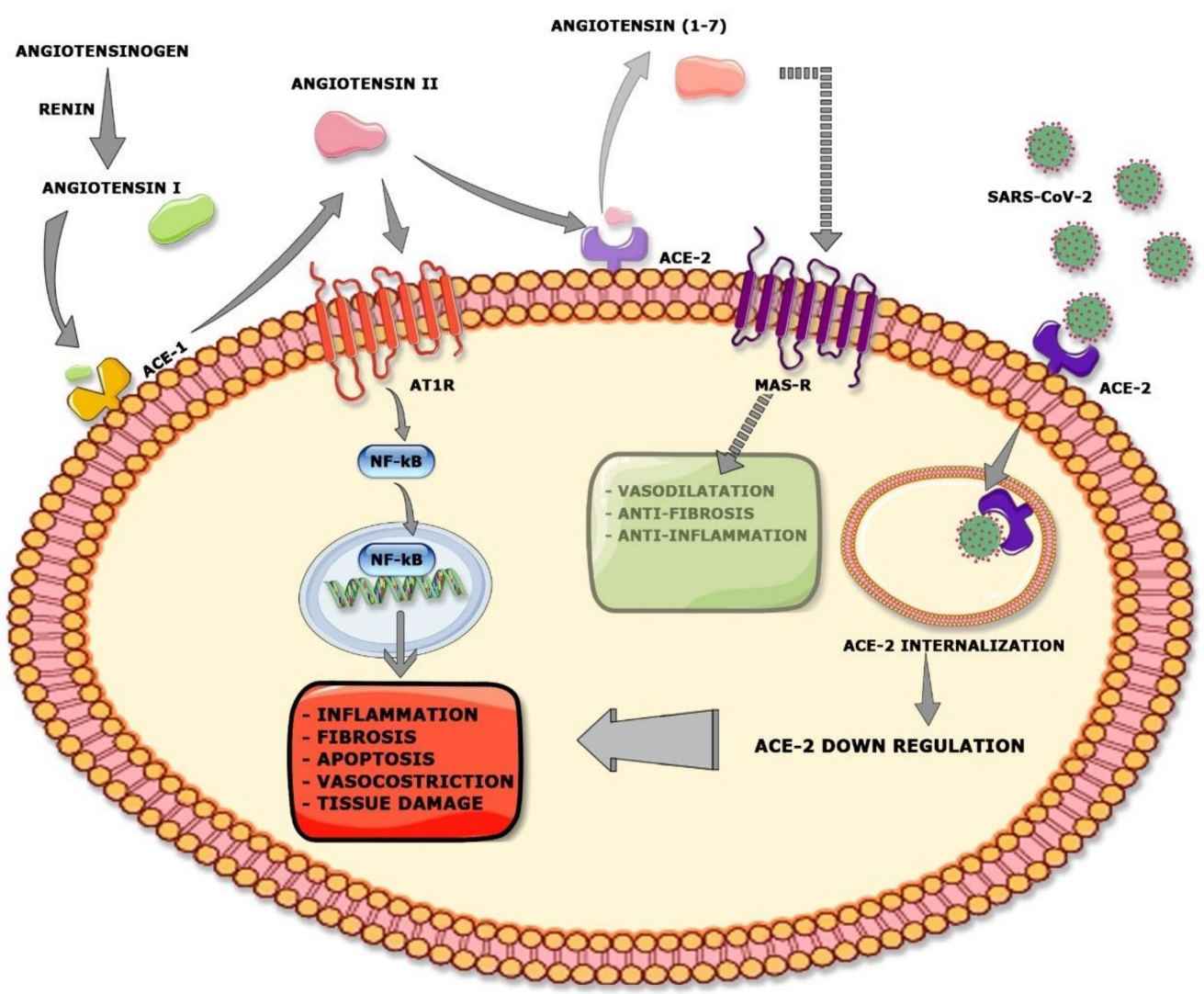

Figure 1. Viral entry mechanism of SARS-CoV-2 and RAS impairment. Angiotensinogen is cleaved into angiotensin I by renin, and then into angiotensin II by ACE-1. Then, Angiotensin II binds angiotensin receptor type I (AT1R) and modulates the gene expression of several inflammatory cytokines via NF- $\mathrm{kB}$ signaling, inducing deleterious effects (i.e., inflammation, fibrosis, apoptosis, vasoconstriction, and tissue damage). In normal conditions with a balanced RAS, both ACE-1 and ACE-2 are activated. Therefore, ACE-2 counteracts AT1R activation, inducing the cleavage of angiotensin II into angiotensin 1-7. Angiotensin 1-7 interact with the MAS receptor (MAS-R), promoting vasodilatation, and anti-fibrotic and anti-inflammatory processes. SARS-CoV-2 enters the host cell by binding with the ACE-2 receptor. The virus endocytosis causes a decrease of ACE-2 expression on the surface membrane that results in a down-regulation of the MAS-R pathway (faded image). Moreover, the accumulation of Angiotensin II induces an overactivation of AT1R signaling, increasing the cell damage.

Indeed, the presence of SARS-CoV-2 RNA and the shedding of viable SARS-CoV-2 in the urine of COVID-19 patients indicates that the virus has a direct interaction with the renal tubules [60]. Moreover, SARS-CoV-2 viral particles have been found in kidney samples from autopsied patients [14,61].

Recently, Diao et al. demonstrated that SARS-CoV-2 induced acute tubular necrosis by direct cytopathic effects [13]. The analysis of renal biopsies revealed the presence of viral nucleoprotein (NP) antigens in in the cytoplasm of tubular cells [13]. Su et al. showed the presence of viral particles in tubular cells and podocytes [14]. It is reasonable that the virus could infect renal parenchyma by first invading podocytes and then binding ACE-2 in the proximal tubule [14].

The principal hallmark of renal dysfunction in patients with COVID-19 is mild or moderate proteinuria [62]. As is well known, a little fraction of plasma protein is filtered in the renal glomeruli, and most of them are reabsorbed by proximal tubular cells. The integrity and functionality of the glomerular filtration barrier depends on its three components: endothelial cells, the glomerular basement membrane, and podocytes [63-65]. The involvement of podocytes in COVID-19 disease has been recently determined, and it is plausible that the increased proteinuria is the result of direct cell infection and changes in RAS homeostasis [66]. Indeed, if a pathological process induces an alteration 
of RAS homeostasis and an increase of Ang II levels, podocytes acquire a dysfunctional phenotype, resulting in single nephron hyperfiltration and increased proteinuria [67].

Certainly, tubular damage can also augment proteinuria, usually with a mild intensity [62]. However, there is no evidence that supports that the alterations of the RAS system could influence tubular behavior, determining the decrease of the protein adsorption.

In lung cells, the viral entry is mediated by ACE-2 and the viral S protein priming serine protease TMPRSS2 [24], whereas renal proximal tubular cells express low levels of TMPRSS2 [68]. Interestingly, several studies have shown that renal cells present elevated levels of other proteases, including cysteine protease cathepsin B/L, glutamyl aminopeptidase, and serine protease dipeptidyl peptidase 4 (DPP4), which might facilitate the binding of SARS-CoV-2 to ACE-2 and viral entry [31]. These potential cofactors play a critical role in SARS-CoV and MERS-CoV infection, and may play an important role in the internalization of SARS-CoV-2 [31].

However, neither of the recent studies have unequivocally demonstrated the direct viral entry in renal cells and consequent viral replication and cytopathy in COVID-19 patients [69]. Therefore, cohort studies on renal biopsies that include a large number of patients with COVID-19 are needed in order to definitively assess the scientific evidence of direct viral tropism.

\section{Role of Immune Response in SARS-CoV-2-Associated AKI}

The pathogenesis of SARS-CoV-2-induced AKI is multi-factorial (Figure 2). Both direct viral damage and the host immune response are likely to contribute to kidney injury in patients with SARS-CoV-2 infection.

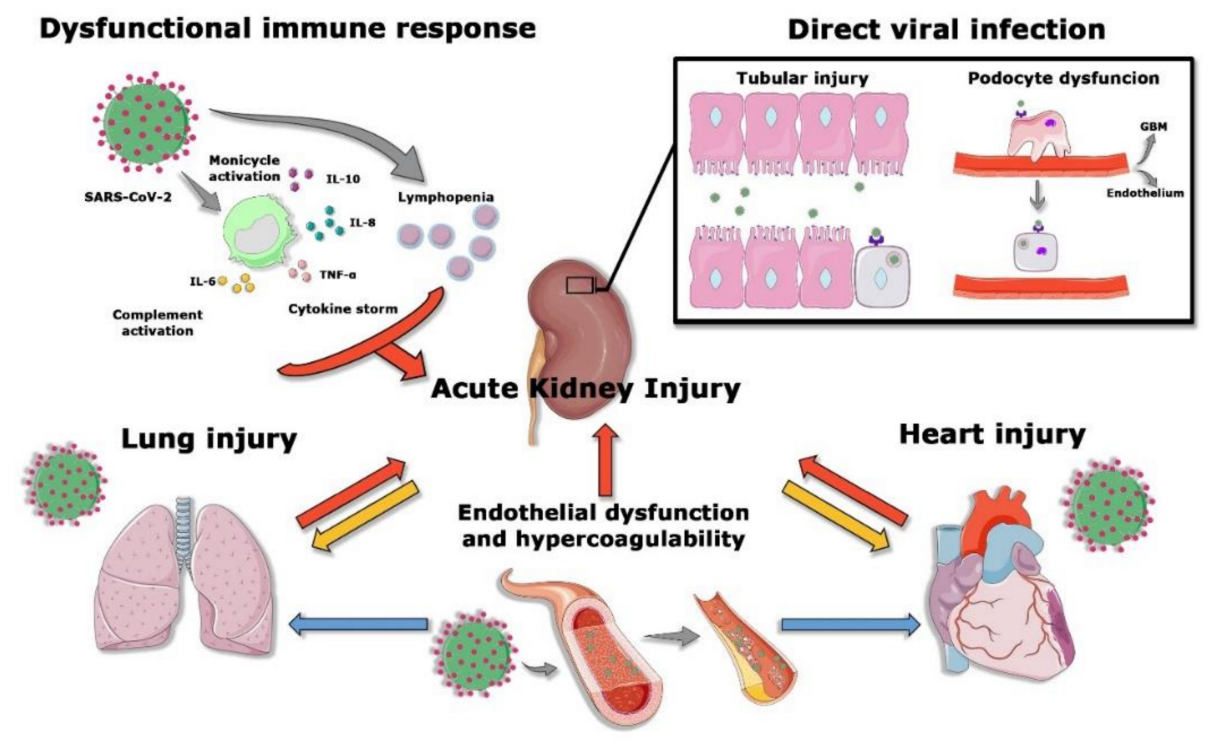

Figure 2. Etiology of AKI in SARS-CoV-2 infection. Several mechanisms contribute to AKI development in COVID-19 patients. The dysfunctional immune response characterized by the production of various proinflammatory cytokines, the complement system activation, and the T cell impairment lead to renal injury. On the other hand, SARS-CoV-2 penetrates tubular cells and podocytes, leading to acute tubular necrosis and podocyte dysfunction. The endothelial damage and the activation of the coagulation system participate in the development of AKI. Moreover, both lung and heart injury affect renal function. In the same way, the kidney hampers lung and heart dysfunction.

Certainly, SARS-CoV-2 infection is the principal trigger for COVID-19 disease, but the dysfunctional host immune response is considered to be the major player in the progression of the severe disease [70].

Clinical evidence suggests that this response is divided into two phases [71]. During the first phase, SARS-CoV-2 infects the lung epithelial cells of the distal airways, which highly express ACE- 2 on the apical surface membrane $[27,70,72]$. Thus, the infection and the subsequent replication of the virus 
induces the apoptosis/pyroptosis of the host cells with extensive tissue damage and vascular leakage [70]. Pyroptosis is a highly inflammatory form of programmed cell death triggered by cytopathic viruses, such as SARS-CoV-2 [70]. In most cases, this leads to a local inflammatory response through the recruitment of immune cells from the blood circulation into the infected site, which eradicates the pathogen. Then, as the immune response decreases, the patients recover [70].

However, in some cases, the general state of health, the genetic background, the prolonged presence of viral antigens, and the continued release of pro-inflammatory factors and damage-associated molecular patterns (DAMPS) from damaged or dying cells cause an exacerbated immune response that induces the progression of the disease [70,71]. Therefore, the local immune response turns into a systemic inflammatory response, also termed cytokine release syndrome (CRS), that leads to acute lung injury and ARDS, with detrimental effects across all organs and subsequent multi-organ dysfunction [70].

It remains unclear whether the disease's progression is related to ongoing virus replication. Several studies have shown that the viral replication and titres in respiratory tract samples are on the decline even before the beginning of critical illness signs of pneumonia both in SARS-CoV and SARS-CoV-2 infection [73-75]. However, Zhou et al. showed that viral RNA was still detectable in non-survivors up until the point of death, demonstrating that the failure of the immune response in eradicating the viral infection is another hallmark of poor outcomes [76].

\section{Viral Sepsis: Cytokine Storm and Multiorgan Dysfunction}

The host response to viral infection, including the production of various proinflammatory cytokines and the activation of $\mathrm{T}$ cells, $\mathrm{CD} 4^{+}$and $\mathrm{CD} 8^{+} \mathrm{T}$ cells, is necessary to control the viral replication and diffusion [77]. In addition, the tissue damage caused by the cytopathic virus amplifies the inflammatory response through the local recruitment of immune cells that release high levels of pro-inflammatory cytokines. The secretion of multiple cytokines, also termed CRS, leads to further tissue injury [78]. As in severe sepsis, the cytokine storm plays an important role in the immunopathology of COVID-19 [79,80].

Different levels of pro-inflammatory cytokines and chemokines were observed in COVID-19 disease from the mild to the severe stage [78]. A retrospective analysis, performed in SARS-CoV-2 infected patients, showed higher levels of the expression of IL-1 $\beta$, IL-1RA, IL-7, IL-8, IL-10, IFN-y, monocyte chemoattractant peptide (MCP)-1, granulocyte-colony stimulating factor (G-CSF), macrophage inflammatory protein (MIP)-1A, MIP-1B, and tumor necrosis factor-alpha (TNF- $\alpha$ ). In addition, higher levels of IL-2, IL-7, IL-17, IL-10, MCP-1, MIP-1A, and TNF- $\alpha$ were found in ICU patients [81].

Yang et al. showed that the severity of lung injury was strongly associated with increased plasma levels of IL-1 $\alpha$, IL-1ra, IL-2, IL-7, IL- 10, IL-17, IFN-y, inducible interferon protein (IP)-10, and G-CSF, which are positively related to SARS-CoV-2 viral titres [82].

Among all of the cytokines, IL-6 plays an important role in CRS. The serum levels of IL-2 Receptor (IL-2R) and IL-6 are positively correlated with the severity of COVID-19 disease [83]. In other studies, the increase of IL-6 was found in mildly- and severely-ill patients. However, Wang et al. found that the pulmonary infiltration area, the damaged lung area, is closely associated with increased levels of IL-6 [84].

Interestingly, increased serum levels of IL-6 are also associated with worse outcomes in AKI, and may be considered to be a good biomarker for the early diagnosis and prediction of clinical outcomes such as the need for dialysis, and mortality [85].

Several clinical and experimental studies have demonstrated that the local activation of IL-6 is implicated in renal autoimmune and inflammatory diseases [85]. Moreover, renal resident cells, including podocytes, endothelial cells, mesangial cells, and tubular epithelial cells can secrete IL-6 under certain conditions [85]. In the meantime, all of these cells, as well as immune and inflammatory cells actively respond to IL-6, and contribute to the exacerbation of renal damage in acute and chronic renal injury [85]. More importantly, the serum increase of IL-6 in AKI has been proven to have a strong correlation with higher alveolar-capillary permeability and pulmonary hemorrhage [86]. In addition, 
lung damage may also cause renal medullary hypoxia that subsequently contributes to acute tubular necrosis [87]. Therefore, lung-kidney crosstalk is characterized by bidirectional damage [87].

Recently, it was found that IL-6R-neutralizing mAb tocilizumab ameliorates the clinical response in kidney transplant recipients with severe SARS-CoV-2 infection [88].

The importance of IFN- $\gamma$ has been recently explored in COVID-19 disease [89,90]. Hu et al. demonstrated that the progression of lung injury and fibrosis was inversely related to IFN- $\gamma$ serum levels in patients with severe SARS-CoV-2 infection [89]. As is well known, IFN- $\gamma$ is a pleiotropic cytokine with anti-fibrotic activities, and several studies have reported its potential effectiveness in the prevention of fibrosis in renal parenchyma [89,91,92]. Moreover, lower levels of IFN- $\gamma$ are associated with dysfunctional immune response [93-95] and renal tubulointerstitial damage [96] in chronic kidney disease progression [97]. Therefore, IFN- $\gamma$ could be considered a good biomarker for the prognosis of severe forms of COVID-19 disease, and its potential therapeutic value needs future investigations.

The heart-kidney axis could also contribute to AKI in patients with COVID-19 [98]. It was found that the combination of both decreased cardiac output and acute viral myocarditis induces renal vein congestion, hypotension and subsequent hypoperfusion, lowering the glomerular filtration rate [98]. In addition, AKI developed, on average, nine days after admission, along with secondary infections and acute cardiac damage [99]. On the other hand, the kidney is an early responder to the myocardial dysfunction, and it could lead to hypovolemic shock, with detrimental effects on heart and lung function $[87,100]$.

Taken together, these results indicate that the pathogenetic mechanisms of COVID-19 disease reflect the maladaptive host immune response observed in sepsis, and the advances in the septic field could have a great impact in therapeutic options [78].

\section{Immune Cell Response Against SARS-CoV-2 Infection}

During viral infection, there is a significant increment of neutrophils, leukocytes, and the neutrophil-lymphocyte-ratio (NLR) in severe forms of COVID-19 compared to mild cases. Several studies have reported low levels of $\mathrm{T}$ cells in the peripheral blood of patients with the severe disease $[81,101]$. This condition of lymphopenia suggested that the $\mathrm{T}$ cells moved to local infected site to resolve the infection. Moreover, patients with the severe disease presented increased plasma levels of proinflammatory cytokines, including interleukin IL-6, IL-10, G-CSF, MCP1, MIP1 $\alpha$, and TNF- $\alpha[81,101]$. Interestingly, both the $\mathrm{CD} 4^{+}$and $\mathrm{CD} 8^{+} \mathrm{T}$ cells were hyperactive in these patients, as shown by the increased expression of CD69, CD38 and CD44 on their surface membrane. However, Zheng et al. demonstrated that $\mathrm{T}$ cells expressed a higher percentage of checkpoint receptor $\mathrm{Tm} 3^{+} \mathrm{PD}-1^{+}$, suggesting that the $\mathrm{T}$ cells were also exhausted [102]. The exhaustion of antiviral CD8 ${ }^{+} \mathrm{T}$ cells in COVID-19 syndrome was also demonstrated by the expression of NK group 2 member A (NKG2A), another marker for lymphocyte breakdown [102]. This condition was associated with a worse outcome in COVID-19 patients [102].

Another relevant finding was the increased co-expression of IFN- $\gamma$ and granulocyte-macrophage colony-stimulating factor (GM-CSF) in the $\mathrm{CD}^{+} \mathrm{T}$ cells of COVID-19 patients with severe disease progression [101]. GM-CSF is released upon the virus infection, and it plays a critical role in innate immune cell differentiation and $\mathrm{T}$ cell function, and can also augment local damage [103].

So far, it remains unclear whether the $T$ cell impairment in COVID-19 disease is due to a direct $T$ cell infection or an indirect mechanism mediated by SARS-CoV-2, such as altered antigen-presenting cell (APC) function, since APCs are important for T cell activation. In addition, $\mathrm{T}$ cells are important for the control and counteraction of the overactivation of the immune response during viral infection [104,105]. Therefore, during SARS-CoV-2 infection, the T lymphopenia could aggravate local and systemic inflammation, and multi-organ damage. Accordingly, Liu et al. observed that the T cell count's reduction was reversely correlated with the kinetic changes of most of the examined cytokine levels in severe COVID-19 patients [106]. When the T cell count dropped down after 4-6 days from the beginning of the disease, the serum levels of IL-10, IL-2, IL-4, TNF- $\alpha$ and IFN- $\gamma$ significantly increased, 
while the recovering of the T cells number was associated with the decrease of IL-6, IL-10, IL-2, IL-4, TNF- $\alpha$, and IFN- $\gamma$ levels. Therefore, the lymphocyte count may bear a prognostic impact for COVID-19 patients [106].

In particular, the patients with a severe progression of COVID-19 disease presented remarkably lower levels of helper $\mathrm{T}$ cells and regulatory $\mathrm{T}$ cells. As is well known, the regulatory $\mathrm{T}$ cells are involved in the maintenance of the immune homeostasis through the suppression of the activation, proliferation, and proinflammatory function of most lymphocytes, including $\mathrm{CD} 4^{+} \mathrm{T}$ cells, $\mathrm{CD} 8^{+} \mathrm{T}$ cells, NK cells, and B cells $[107,108]$. In addition, the percentage of naïve helper T cells is augmented while the number of memory helper $\mathrm{T}$ cells and $\mathrm{CD} 28^{+}$cytotoxic suppressor $\mathrm{T}$ cells declines in severe COVID-19 disease [81,109]. Therefore, the loss of the equilibrium between naïve T cells and memory $\mathrm{T}$ cells impacts the efficacy of the host immune response [110]. In addition, Wang et al. highlighted a strong relationship between inflammatory markers-including ESR, CRP and IL-6-and the lymphopenia [111]. (Figure 3).

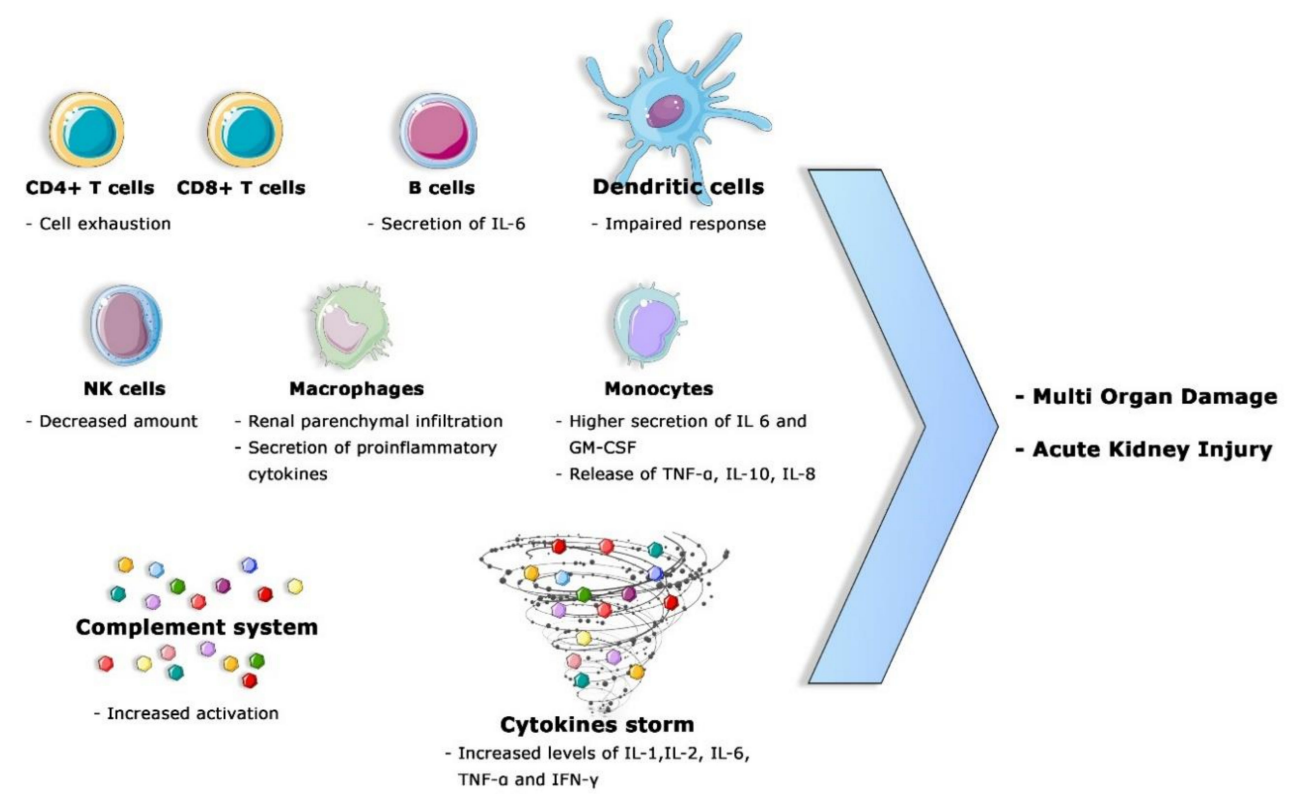

Figure 3. Principal mechanisms of dysfunctional immune response associated with multi-organ damage and AKI. The most important are T cell exhaustion, a decreased amount of NK, dysfunctional B cell activation, impaired DC response, the higher activation of circulating monocytes, the infiltration of macrophages into the renal parenchyma, the higher secretion of pro-inflammatory cytokines (cytokine storm) and systemic complement activation.

Another important finding was that, during SARS-CoV infection, lung epithelial cells produced IL-6 and IL-8 [112]. As is well known, IL-8 is a chemoattractant factor for neutrophils and T cells. Since a large number of immune cells were found in the lung tissue of patients with COVID-19 disease, lung epithelial cells may actively contribute to immune cell recruitment by the synthesis and the release of several chemoattractant factors [113,114].

Several pieces of evidence suggest that IL-8 has a central role in renal interstitial inflammation. Upon proinflammatory stimulation, renal cells are able to synthetize IL-8, and to increase the recruitment of neutrophils and lymphocytes at the tubule-interstitial level $[115,116]$. In addition, Tang et al. showed that increased levels of albumin and proteinuria could also stimulate the tubular production of IL-8, and it is plausible to hypothesize that similar mechanisms could be observed in SARS-CoV-2- induced AKI [117].

Recently, Zhou et al. showed that the bronchoalveolar fluid (BALF) from patients with severe COVID-19 presented elevated levels of CCL2 and CCL7, two chemokines that are involved in the recruitment of CC-chemokine receptor 2-positive monocytes [118]. Moreover, Liao et al. demonstrated 
that the mononuclear phagocyte (MNP) compartment was strongly increased in patients with severe COVID-19 compared to patients with the mild disease or healthy controls [119]. In addition, the MNP compartment was principally characterized by inflammatory monocyte-derived macrophages [119]. The inflammatory behavior of these macrophages is in line with the results obtained by RNA-seq in the study of Zhou et al. [118,119]. Moreover, a subset of these macrophages expressed genes involved both in inflammatory and fibrotic processes [118], such as those observed in liver cirrhosis [120]. Therefore, the invasiveness and the pathogenicity of these infiltrating macrophages could be correlated not only to acute inflammation but also to the lung fibrotic damage that was observed in patients under mechanical ventilation [121].

Although the host immune cells infiltrate the infected tissue in order to counteract viral replication, a dysfunctional immune response could induce increased renal damage and promote fibrosis, cell apoptosis, and endothelial dysfunction. Indeed, renal biopsies of SARS-CoV-2 patients presented the infiltration of high levels of $\mathrm{CD} 8^{+}$macrophages into the tubulo-interstitium, indicating that the proinflammatory cytokines derived from macrophages could increase renal damage [13]. In addition, $\mathrm{CD}^{+} \mathrm{T}$ cells were found only in restrained numbers, while $\mathrm{CD} 4^{+} \mathrm{T}$ cells and $\mathrm{CD} 56^{+} \mathrm{NK}$ cells were observed in great amounts [13].

Moreover, a significant expansion of $\mathrm{CD} 14^{+} \mathrm{CD} 16^{+}$inflammatory monocytes was observed in the peripheral blood of COVID-19 patients with severe pulmonary syndrome from ICU compared with those patients who did not require ICU hospitalization [101,122]. These circulating monocytes responded to granulocyte macrophage-colony stimulating factor (GM-CSF) released by pathological $\mathrm{T}$ cells, and initiated tissue damage. Interestingly, they were also able to synthetize and secrete GM-CSF and IL-6 [101,122]. Therefore, the significantly higher secretion of IL 6 and GM-CSF in ICU patients induced an inflammatory storm with deleterious lung damage and an increased mortality rate [101].

The role of B cells in SARS-CoV-2 immune response is more controversial [123]. Given that only patients with agammaglobulinemia had a mild course of COVID-19, B lymphocytes could accelerate the inflammatory process [123]. The role of inflammation in aggravating the clinical conditions of COVID-19 patients is well known and has been confirmed in several studies. B cells are able to produce IL-6, which induces germinal center formation and increases the level of inflammation. In an experimental animal model, the decrease of B-cell-derived IL-6 counteracts the spontaneous autoimmune germinal center formation, preventing systemic autoimmunity [124]. In addition, the role of $B$ cells in inducing lung inflammatory damage is also underlined by the presence of granulomatous lymphocytic interstitial lung disease in patients with common variable immunodeficiency that could be treated by B-cell-depleting drugs [125]. Therefore, the dysfunctional immune response to SARS-CoV-2 infection could be counteracted by modulating the $\mathrm{B}$ cell response and blocking the release of inflammatory cytokines by monocytes and dendritic cells [123].

\section{Complement System Activation and Renal Implications}

Emerging evidence suggests that the complement system plays a key role in the pathogenic mechanisms of SARS-CoV-2 infection [126]. As is well known, the complement system is the first host immune response that protects against infectious agents such as viruses [127]. However, the exacerbated activation of the complement system can increase the inflammatory response, coagulation process, and cell lysis, leading to local severe tissue damage and systemic inflammation associated with multiple organ failure $[51,128,129]$.

Recently, Diao et al. analyzed renal biopsies from six patients with severe COVID-19, and observed abundant complement deposition on renal tubular cells associated with tubular necrosis and acute renal failure, demonstrating that SARS-CoV-2 infection contributes to complement activation and renal damage [126]. In addition, Gao et al. demonstrated the deposition of several complement factors-such as mannose-binding lectin (MBL), C4, C3 and C5b-9—on the surface membrane of different cells of the lung parenchyma [126,130]. Interestingly, they observed that SARS-CoV-2 N protein enhances mannan-binding lectin serine protease 2 (MASP-2) activity and increases C4b deposition. 
Therefore, the opsonization of SARS-CoV-2 by MBL triggers the activation of the lectin pathway and the subsequent deposition of complement factors. Moreover, they also found a relevant increase of the anaphilotoxin C5a in the sera of critically ill patients with SARS-CoV-2 infection [126,130].

Moreover, as observed for the lectin pathway, the classical pathway activation plays a pathogenic role in tissue injury. In particular, in SARS-CoV infection, the binding of autoantibodies to damaged cells mediates the complement activation, leading to further cell damage through complement-mediated cytotoxicity [131].

Studies in deficient mice for $\mathrm{C} 3$ have shown that the activation of $\mathrm{C} 3$ is essential for viral clearance and protection against infection [132]. Indeed, the absence of complement activation in these mice was associated with the development of severe bronchitis, bronchiolitis, and vasculitis, and increased inflammatory cells in the lung tissue. However, C3-deficient mice infected with SARS-CoV showed less respiratory dysfunction, and fewer lung pathology changes and inflammatory infiltrates in the lung parenchyma compared to wild-type mice [130].

The contrasting results from these studies highlight the complex functions of the complement system in viral infection. In this context, C3 inhibitors could not obtain positive effects in COVID-19 disease, since complement activation favors viral clearance [130]. Otherwise, the use of C5 inhibitors limit the C5-b9 formation and the subsequent cell damage [133,134], but also assures the C 3 activation and the opsonization of SARS-CoV-2 for removal by immune cells [130].

In MERS and SARS-CoV infections, several studies have shown that local and systemic C5 activation exerts a critical role in virus-induced lung damage and mortality [130]. The role of $C 5$ and C5a in SARS-CoV-2 infection has been described by Gao et al., who observed an improvement of clinical conditions in two patients that received multiple injections of the C5a antibody [126].

Taking into account these studies, the prevention of the complement terminal complex formation and the use of $\mathrm{C} 5$ inhibitors could be a promising approach to the reduction of the lung injury and systemic inflammation associated with severe forms of viral infection, such as COVID-19 disease.

\section{Systemic Endothelial Dysfunction and Hypercoagulability in COVID-19 Disease}

As has previously been described, the pathogenic mechanisms of SARS-CoV-2 infection reflect the principal hallmarks of sepsis disease [135]. Since the impairment of endothelial function plays a central role in septic shock and organ dysfunction, and has been suggested to be a predictor of mortality in sepsis [136], it is reasonable that the endothelium could be a more plausible player and target in COVID-19 disease.

The experimental studies performed by our group on sepsis-induced AKI contributed to highlight the role of the vascular compartment in systemic inflammatory diseases $[16,137,138]$. In the course of sepsis, we observed that endothelial cells and pericytes acquired a pro-fibrotic and dysfunctional phenotype, promoted the activation of the coagulation cascade, compromised parenchymal perfusion, and increased inflammation and fibrosis $[16,137,139]$. Therefore, the endothelium it is not just a passive element during sepsis, but rather actively contributes to the amplification of the inflammatory response and multi-organ damage [16].

Recent evidence supports the importance of endothelial dysfunction in COVID-19 syndrome, in addition to respiratory disease $[140,141]$. Varga et al. analyzed the vascular beds of several organs in COVID-19 patients, and demonstrated that the endothelial cells accumulated viral elements in their cytoplasm and promoted the recruitment of inflammatory cells, leading to endothelial dysfunction [140,141].

In another study, the histopathology analysis of kidney biopsies of deceased COVID-19 patients revealed endothelial cell swelling, and-in three of these cases-the presence of fibrin thrombus in glomerular capillary loops that was strongly associated with severe parenchymal $[14,126]$.

As is well known, the activation of complement system is considered one of the key events in sepsis disease [142]. Its principal function for the host is to identify and neutralize the invading pathogens through the opsonization of foreign surfaces and the formation of the terminal complex C5b-9 (MAC), 
which leads to the lysis of the pathogen [142]. However, the activated complement exerts detrimental effects on the host endothelium through the formation of MAC on the surface membrane [142]. The dysfunctional activation of endothelial cells also occurs also during renal ischemia reperfusion injury, in which the complement activation that orchestrates the immunological and inflammatory process also controls the endothelial behavior and response [51,143,144]. Indeed, in our previous studies, we demonstrated that the complement—in particular C3a and C5a-enhanced the endothelial and pericytes to mesenchymal transition process and tubular damage, inducing vascular rarefaction and early fibrosis, with the loss of renal function [138,143-146].

The role of C5 activation products in COVID-19-associated vasculopathy is supported by several pieces of evidence that demonstrate the presence of $\mathrm{C} 5 \mathrm{~b} 9$ deposits not only in the microvasculature of lung tissue but also in many organs, including the heart and blood vessels, kidneys, gut, and brain [140].

Another important finding is that the erythrocyte aggregation in the peritubular and glomerular capillaries of the renal parenchyma in COVID-19 patients was associated with oxidative stress, inflammation and complement activation that aggravated the microvascular damage [14]. Moreover, the occlusion of the microvascular lumens by erythrocyte aggregates was responsible for several vascular lesions [14]. Even if the endothelial cells did not express ACE-2 in normal conditions, Varga et al. demonstrated that endothelitis was a common feature of organ dysfunction, and endothelial cells could be involved directly and indirectly in SARS-CoV-2 infection [88]. Interestingly, a recent study showed that SARS-CoV-2 could infect host cells through the binding of an alternative cell receptor known as CD147, which is a transmembrane glycoprotein which is highly expressed on all endothelial cells [147].

Emerging evidence has shown that SARS-CoV-2 may play an important role in inducing coagulopathy [148]. Several analyses of the hematological profile of COVID-19 patients showed high plasma levels of reactive protein C, fibrinogen, D-dimer, and ferritin, which are associated with thrombocytopenia [148]. In addition, clinical and autopsy reports from China and the U.S. have shown the presence of disseminated intravascular coagulation, with evidence of microangiopathy in several organs, including the kidneys [148]. Indeed, the activation of monocytes and macrophages, the increase of pro-inflammatory cytokines, the activation of the complement system, and the release of DAMPs can cause the activation of endothelial cells to express tissue factor (TF), and the subsequent activation of the coagulation cascade predisposing to hypercoagulability.

The hypercoagulability predisposes to the development of cortical necrosis, and therefore leads to irreversible renal damage [149].

Together, these studies point to another important rationale to find therapies that could preserve the endothelium, and inhibit viral replication, hypercoagulability, and the systemic inflammatory response.

\section{Therapeutic Strategies in SARS-COV-2-Induced AKI}

Although bacterial sepsis is not a hallmark of SARS-CoV-2 disease, the overwhelmed immune response, as previously described, underlined the similar pathological conditions of a severe CRS with multiple organ dysfunction [150]. There is no definite treatment for this complex disease, and the supportive care treatment is considered the best strategy for patients with COVID-19-induced AKI in the ICU [32].

The decrease of volume-trauma and barotrauma through the use of lung-protective ventilation prevents the occurrence of new or worsening AKI by limiting the ventilation-induced hemodynamic effects and the cytokine cargo on the kidney [151]. Another strategy is to regulate the fluid balance according to volume responsiveness and tolerance assessment. In this way, normal volume status could be restored in order to avoid volume excess and reduce the risk of pulmonary edema, right ventricular overload, congestion, and subsequent AKI [87].

If the standard care treatment fails, renal replacement therapy should be considered an adequate treatment in order to assure organ support and prevent AKI. In particular, blood purification could be considered the best option to restore 'immune homeostasis' in this complex disease, which is characterized by a dysregulated host response to infection and consequent multiple organ 
dysfunction [87]. Extracorporeal blood purification is proposed as an adjuvant therapy for COVID-19 disease, aiming at controlling the associated dysregulation of the immune response through the removal of increased cytokines and chemical mediators [87]. This approach comprises a group of techniques including plasma exchange, adsorption, perfusion, and continuous renal replacement therapy (CRRT) [138,152].

Among them, CRRT could be considered the best strategy for severe forms of COVID-19 characterized by AKI, systemic inflammatory response syndrome, multiple organ dysfunction syndrome, and CRS. Indeed, the emerging literature highlights that the number of patients with AKI requiring CRRT is unprecedented in modern history [53]. These therapeutic interventions have proved fundamental as lifesaving measures in patients with severe forms of COVID-19 and impaired renal function [153-155].

Park et al. [156] showed that CRRT reduced the serum levels of IL6 and IL8 in septic disease. Moreover, a randomized clinical trial underlined that the early use of CRRT could significantly reduce the index of mortality in critically ill patients with renal damage [157]. All of these studies demonstrate that the timely use CRRT may be effective in reducing the highest peak of the cytokine storm in severe forms of COVID-19.

In April 2020, the Food and Drug Administration (FDA) temporarily approved the use of adsorption/CytoSorb therapy in the management of CRS in COVID-19 patients [158,159]. Considering several clinical studies on Cytosorb performance, the FDA permitted the use of this adsorbent membrane in COVID-19 disease in order to reestablish the equilibrium between pro- and anti-inflammatory mediators, and it is considered to be a 'salvage,' or 'compassionate use' intervention when other pharmacological treatments are ineffective [87].

A controlled trial has been conducted on critically ill COVID-19 patients, showing the efficacy of cartridges in adsorbing inflammatory cytokines such as IL-6, and in improving the general conditions in most of recruited patients [160]. In a case report, extracorporeal blood purification has been proven to effectively remove the released inflammatory cytokines and to improve renal function in terms of serum creatinine and urine output [161].

Certainly, the nonspecific or specific removal of some DAMPS or pathogen-associated molecular pattern molecules (PAMPs) plays a key role to counter the systemic peaks of cytokine concentrations, which are disproportionate and counterproductive in severe inflammatory diseases, such as COVID-19. However, patients differ from each other based on their inflammatory phenotype, and they develop different levels of cytokines in their blood [162].

To our knowledge, there is a paucity of data concerning the effects on mortality and favorable outcomes after AKI of CRRT versus other therapeutic strategies. Given the rapid continuous expansion of COVID-19 literature, many cohort studies regarding the management of AKI in the setting of COVID-19 had limitations in their description of the details of CRRT and other treatments.

Recently, Wilbers et al. investigated the mortality rate and renal recovery in patients with AKI and RRT due to COVID-19. They showed a comparable mortality index in the RRT versus non-RRT group in a retrospective cohort study. In addition, neither group required RRT after ICU discharge [163]. In another retrospective cohort study, Yang et al. analyzed COVID-19 patients undergoing invasive mechanical ventilation, comparing patients who received CRRT treatment and those treated with conventional standard therapies (without CRRT) [164]. Interestingly, CRRT was associated with prolonged survival in COVID-19 patients [164].

In an in-depth review, Ronco et al. indicated practical recommendations for CRRT in COVID-19 patients, highlighting several criteria including clinical conditions, laboratory parameters, and AKI biomarkers, which are useful when defining the effective sequential extracorporeal therapies in clinical practice to avoid renal damage. Further research is needed in order to establish the importance of the early initiation of RRT and sequential extracorporeal therapies in the management of COVID-19 patients. 


\section{Conclusions}

In brief, there is a high incidence of AKI in critical ill patients with COVID-19. The exact mechanism of this renal impairment has not yet been clarified. In the absence of specific treatments, supportive care and blood purification techniques for critically ill patients with renal injuries are considered to be the best approaches both for clinical management and to increase the probability of a favorable outcome.

Because the mortality rate of critically ill SARS-CoV-2 patients with AKI is three times higher than for those without AKI, it is important to diagnose AKI in a timely fashion. Increasing the knowledge of the pathogenesis of COVID-19 associated AKI could suggest targeted interventions that should modulate the severity of kidney failure and significantly improve the clinical outcomes of COVID-19 patients.

Author Contributions: Conceptualization, writing and editing of the paper by A.S., G.C. and G.S.N. shared senior authorship. G.C. and E.R. revised the manuscript. B.I., G.S. and L.G. contributed substantially to the work reported by the critical revisions and draft editing. A.S. conceived the figures. All authors have read and agreed to the published version of the manuscript.

Funding: Supported by University of Bari 'Aldo Moro', the Ministry of Education, University and Research (European Union-European Social Fund, PON R\&I 2014 -2020, Azione I.2 “Attrazione e Mobilità Internazionale dei Ricercatori"-AIM 1810057-activity 2 granted to A.S.), and by University of Foggia (Progetti di Ricerca di Ateneo 2019 granted to G.S.N.).

Conflicts of Interest: The authors declare no conflict of interest.

\section{References}

1. Ritchie, H.; Ortiz-Ospina, E.; Beltekian, D.; Mathieu, E.; Hasell, J.; Macdonald, B.; Giattino, C.; Roser, M.; Yunits, B.; van Woerden, E.; et al. Coronavirus Pandemic (COVID-19)-Deaths. Available online: https://ourworldindata.org/coronavirus?te=1\&nl=nicholas-kristof\&emc=edit_nk_20200624 (accessed on 20 November 2020).

2. Gagliardi, I.; Patella, G.; Michael, A.; Serra, R.; Provenzano, M.; Andreucci, M. COVID-19 and the Kidney: From Epidemiology to Clinical Practice. J. Clin. Med. 2020, 9, 2506. [CrossRef]

3. Sun, P.; Lu, X.; Xu, C.; Sun, W.; Pan, B. Understanding of COVID-19 based on current evidence. J. Med. Virol. 2020, 92, 548-551. [CrossRef] [PubMed]

4. Perico, L.; Benigni, A.; Remuzzi, G. Should COVID-19 Concern Nephrologists? Why and to What Extent? The Emerging Impasse of Angiotensin Blockade. Nephron 2020, 144, 213-221. [CrossRef] [PubMed]

5. Aylward, B.; Liang, W. Report of the WHO-China Joint Mission on Coronavirus Disease 2019 (COVID-19); WHO: Geneva, Switzerland, 2020; pp. 16-24.

6. Lu, R.; Zhao, X.; Li, J.; Niu, P.; Yang, B.; Wu, H.; Wang, W.; Song, H.; Huang, B.; Zhu, N.; et al. Genomic characterisation and epidemiology of 2019 novel coronavirus: Implications for virus origins and receptor binding. Lancet 2020, 395, 565-574. [CrossRef]

7. Wu, A.; Peng, Y.; Huang, B.; Ding, X.; Wang, X.; Niu, P.; Meng, J.; Zhu, Z.; Zhang, Z.; Wang, J.; et al. Genome Composition and Divergence of the Novel Coronavirus (2019-nCoV) Originating in China. Cell Host Microbe 2020, 27, 325-328. [CrossRef] [PubMed]

8. Zhang, H.; Penninger, J.M.; Li, Y.; Zhong, N.; Slutsky, A.S. Angiotensin-converting enzyme 2 (ACE2) as a SARS-CoV-2 receptor: Molecular mechanisms and potential therapeutic target. Intensive Care Med. 2020, 46, 586-590. [CrossRef] [PubMed]

9. Zou, X.; Chen, K.; Zou, J.; Han, P.; Hao, J.; Han, Z. Single-cell RNA-seq data analysis on the receptor ACE2 expression reveals the potential risk of different human organs vulnerable to 2019-nCoV infection. Front. Med. 2020, 14, 185-192. [CrossRef]

10. Nadim, M.K.; Forni, L.G.; Mehta, R.L.; Connor, M.J.; Liu, K.D.; Ostermann, M.; Rimmelé, T.; Zarbock, A.; Bell, S.; Bihorac, A.; et al. COVID-19-associated acute kidney injury: Consensus report of the 25th Acute Disease Quality Initiative (ADQI) Workgroup. Nat. Rev. Nephrol. 2020, 16, 1-18. [CrossRef]

11. Ye, M.; Wysocki, J.; William, J.; Soler, M.J.; Cokic, I.; Batlle, D. Glomerular localization and expression of angiotensin-converting enzyme 2 and angiotensin-converting enzyme: Implications for albuminuria in diabetes. J. Am. Soc. Nephrol. 2006, 17, 3067-3075. [CrossRef] 
12. Xu, H.; Zhong, L.; Deng, J.; Peng, J.; Dan, H.; Zeng, X.; Li, T.; Chen, Q. High expression of ACE2 receptor of 2019-nCoV on the epithelial cells of oral mucosa. Int. J. Oral Sci. 2020, 12,1-5. [CrossRef]

13. Diao, B.; Feng, Z.; Wang, C.; Wang, H.; Liu, L.; Wang, C.; Wang, R.; Liu, Y.; Liu, Y.; Wang, G.; et al. Human Kidney is a Target for Novel Severe Acute Respiratory Syndrome Coronavirus 2 (SARS-CoV-2) Infection. medRxiv 2020. [CrossRef]

14. Su, H.; Yang, M.; Wan, C.; Yi, L.X.; Tang, F.; Zhu, H.Y.; Yi, F.; Yang, H.C.; Fogo, A.B.; Nie, X.; et al. Renal histopathological analysis of 26 postmortem findings of patients with COVID-19 in China. Kidney Int. 2020, 98, 219-227. [CrossRef] [PubMed]

15. Fani, F.; Regolisti, G.; Delsante, M.; Cantaluppi, V.; Castellano, G.; Gesualdo, L.; Villa, G.; Fiaccadori, E. Recent advances in the pathogenetic mechanisms of sepsis-associated acute kidney injury. J. Nephrol. 2018, 31, 351-359. [CrossRef] [PubMed]

16. Stasi, A.; Intini, A.; Divella, C.; Franzin, R.; Montemurno, E.; Grandaliano, G.; Ronco, C.; Fiaccadori, E.; Pertosa, G.B.; Gesualdo, L.; et al. Emerging role of Lipopolysaccharide binding protein in sepsis-induced acute kidney injury. Nephrol. Dial. Transplant. 2016, 32, 24-31. [CrossRef]

17. Fiorentino, M.; Grandaliano, G.; Gesualdo, L.; Castellano, G. Acute Kidney Injury to Chronic Kidney Disease Transition. Contrib. Nephrol. 2018, 139, 45-54.

18. Li, Z.; Wu, M.; Guo, J.; Yao, J.; Liao, X.; Song, S.; Han, M.; Li, J.; Duan, G.; Xiaojun, W.; et al. Caution on Kidney Dysfunctions of 2019-nCoV Patients. medRxiv 2020. [CrossRef]

19. Ye, Q.; Wang, B.; Mao, J. The pathogenesis and treatment of the 'Cytokine Storm' in COVID-19. J. Infect. 2020, 80, 607-613. [CrossRef]

20. Hargens, L.L. Replication. In International Encyclopedia of the Social E Behavioral Sciences, 2nd ed.; Elsevier: Amsterdam, The Netherlands, 2015; ISBN 9780080970875.

21. Schoeman, D.; Fielding, B.C. Coronavirus envelope protein: Current knowledge. Virol. J. 2019, 16,1-22. [CrossRef]

22. Shang, J.; Wan, Y.; Luo, C.; Ye, G.; Geng, Q.; Auerbach, A.; Li, F. Cell entry mechanisms of SARS-CoV-2. Proc. Natl. Acad. Sci. USA 2020, 117, 11727-11734. [CrossRef]

23. Wang, Q.; Zhang, Y.; Wu, L.; Niu, S.; Song, C.; Zhang, Z.; Lu, G.; Qiao, C.; Hu, Y.; Yuen, K.Y.; et al. Structural and Functional Basis of SARS-CoV-2 Entry by Using Human ACE2. Cell 2020. [CrossRef]

24. Hoffmann, M.; Kleine-Weber, H.; Schroeder, S.; Krüger, N.; Herrler, T.; Erichsen, S.; Schiergens, T.S.; Herrler, G.; Wu, N.H.; Nitsche, A.; et al. SARS-CoV-2 Cell Entry Depends on ACE2 and TMPRSS2 and Is Blocked by a Clinically Proven Protease Inhibitor. Cell 2020. [CrossRef] [PubMed]

25. Kamo, T.; Akazawa, H.; Suzuki, J.-I.; Komuro, I. Roles of renin-angiotensin system and Wnt pathway in aging-related phenotypes. Inflamm. Regen. 2016, 36, 12. [CrossRef] [PubMed]

26. Li, Y.; Zhou, W.; Yang, L.; You, R. Physiological and pathological regulation of ACE2, the SARS-CoV-2 receptor. Pharmacol. Res. 2020, 157, 104833. [CrossRef] [PubMed]

27. Li, M.Y.; Li, L.; Zhang, Y.; Wang, X.S. Expression of the SARS-CoV-2 cell receptor gene ACE2 in a wide variety of human tissues. Infect. Dis. Poverty 2020, 9, 1-7. [CrossRef]

28. Walls, A.C.; Park, Y.J.; Tortorici, M.A.; Wall, A.; McGuire, A.T.; Veesler, D. Structure, Function, and Antigenicity of the SARS-CoV-2 Spike Glycoprotein. Cell 2020. [CrossRef]

29. Wrapp, D.; Wang, N.; Corbett, K.S.; Goldsmith, J.A.; Hsieh, C.L.; Abiona, O.; Graham, B.S.; McLellan, J.S. Cryo-EM structure of the 2019-nCoV spike in the prefusion conformation. Science 2020, 367, 1260-1263. [CrossRef]

30. Coutard, B.; Valle, C.; de Lamballerie, X.; Canard, B.; Seidah, N.G.; Decroly, E. The spike glycoprotein of the new coronavirus 2019-nCoV contains a furin-like cleavage site absent in CoV of the same clade. Antivir. Res. 2020, 176, 104742. [CrossRef]

31. Soleimani, M. Acute kidney injury in sars-cov-2 infection: Direct effect of virus on kidney proximal tubule cells. Int. J. Mol. Sci. 2020, 21, 3275. [CrossRef]

32. Qian, J.-Y.; Wang, B.; Liu, B.-C. Acute Kidney Injury in the 2019 Novel Coronavirus Disease. Kidney Dis. 2020, 323, 1-6. [CrossRef]

33. Huang, C.; Wang, Y.; Li, X.; Ren, L.; Zhao, J.; Hu, Y.; Zhang, L.; Fan, G.; Xu, J.; Gu, X.; et al. Clinical features of patients infected with 2019 novel coronavirus in Wuhan, China. Lancet 2020, 395, 497-506. [CrossRef] 
34. Chen, N.; Zhou, M.; Dong, X.; Qu, J.; Gong, F.; Han, Y.; Qiu, Y.; Wang, J.; Liu, Y.; Wei, Y.; et al. Epidemiological and clinical characteristics of 99 cases of 2019 novel coronavirus pneumonia in Wuhan, China: A descriptive study. Lancet 2020, 395, 507-513. [CrossRef]

35. Guan, W.; Ni, Z.; Hu, Y.; Liang, W.; Ou, C.; He, J.; Liu, L.; Shan, H.; Lei, C.; Hui, D.S.C.; et al. Clinical characteristics of coronavirus disease 2019 in China. N. Engl. J. Med. 2020, 382, 1708-1720. [CrossRef] [PubMed]

36. Li, Z.; Wu, M.; Yao, J.; Guo, J.; Liao, X.; Song, S.; Li, J.; Duan, G.; Zhou, Y.; Wu, X.; et al. Caution on Kidney Dysfunctions of COVID-19 Patients. SSRN Electron. J. 2020. [CrossRef]

37. Cheng, Y.; Luo, R.; Wang, K.; Zhang, M.; Wang, Z.; Dong, L.; Li, J.; Yao, Y.; Ge, S.; Xu, G. Kidney impairment is associated with in-hospital death of COVID-19 patients. medRxiv 2020. [CrossRef]

38. Yang, X.; Yu, Y.; Xu, J.; Shu, H.; Xia, J.; Liu, H.; Wu, Y.; Zhang, L.; Yu, Z.; Fang, M.; et al. Clinical course and outcomes of critically ill patients with SARS-CoV-2 pneumonia in Wuhan, China: A single-centered, retrospective, observational study. Lancet Respir. Med. 2020, 8, 475-481. [CrossRef]

39. Chen, T.; Wu, D.; Chen, H.; Yan, W.; Yang, D.; Chen, G.; Ma, K.; Xu, D.; Yu, H.; Wang, H.; et al. Clinical characteristics of 113 deceased patients with coronavirus disease 2019: Retrospective study. BMJ 2020. [CrossRef]

40. Hirsch, J.S.; Ng, J.H.; Ross, D.W.; Sharma, P.; Shah, H.H.; Barnett, R.L.; Hazzan, A.D.; Fishbane, S.; Jhaveri, K.D.; Abate, M.; et al. Acute kidney injury in patients hospitalized with COVID-19. Kidney Int. 2020, 98, 209-218. [CrossRef]

41. Pei, G.; Zhang, Z.; Peng, J.; Liu, L.; Zhang, C.; Yu, C.; Ma, Z.; Huang, Y.; Liu, W.; Yao, Y.; et al. Renal involvement and early prognosis in patients with COVID-19 pneumonia. J. Am. Soc. Nephrol. 2020, 31, 1157-1165. [CrossRef]

42. Mohamed, M.M.B.; Lukitsch, I.; Torres-Ortiz, A.E.; Walker, J.B.; Varghese, V.; Hernandez-Arroyo, C.F.; Alqudsi, M.; LeDoux, J.R.; Velez, J.C.Q. Acute Kidney Injury Associated with Coronavirus Disease 2019 in Urban New Orleans. Kidney360 2020, 1, 614-622. [CrossRef]

43. Lin, L.; Wang, X.; Ren, J.; Sun, Y.; Yu, R.; Li, K.; Zheng, L.; Yang, J. Risk factors and prognosis for COVID-19-induced acute kidney injury: A meta-analysis. BMJ Open 2020, 10, e042573. [CrossRef]

44. Shastri, A.; Wheat, J.; Agrawal, S.; Chaterjee, N.; Pradhan, K.; Goldfinger, M.; Kornblum, N.; Steidl, U.; Verma, A.; Shastri, J. Delayed clearance of SARS-CoV2 in male compared to female patients: High ACE2 expression in testes suggests possible existence of gender-specific viral reservoirs. medRxiv 2020. [CrossRef]

45. Mubarak, M.; Tolouian, R.; Pezeshgi, A. Collapsing glomerulopathy following COVID-19 infection; possible relationship with APOL1 kidney risk alleles in African-Americans. Immunopathol. Persa 2020, 6, e18. [CrossRef]

46. Wu, H.; Larsen, C.P.; Hernandez-Arroyo, C.F.; Mohamed, M.M.B.; Caza, T.; Sharshir, M.; Chughtai, A.; Xie, L.; Gimenez, J.M.; Sandow, T.A.; et al. AKI and collapsing glomerulopathy associated with covid-19 and apol1 high-risk genotype. J. Am. Soc. Nephrol. 2020, 31, 1688-1695. [CrossRef] [PubMed]

47. Sharma, Y.; Nasr, S.H.; Larsen, C.P.; Kemper, A.; Ormsby, A.H.; Williamson, S.R. COVID-19-Associated Collapsing Focal Segmental Glomerulosclerosis: A Report of 2 Cases. Kidney Med. 2020, 2, $493-497$. [CrossRef] [PubMed]

48. Chang, J.H.; Husain, S.A.; Santoriello, D.; Stokes, M.B.; Miles, C.D.; Foster, K.W.; Li, Y.; Dale, L.A.; Crew, R.J.; Cohen, D.J.; et al. Donor's APOL1 Risk Genotype and "Second Hits" Associated with De Novo Collapsing Glomerulopathy in Deceased Donor Kidney Transplant Recipients: A Report of 5 Cases. Am. J. Kidney Dis. 2019, 73, 134-139. [CrossRef] [PubMed]

49. Wang, D.; Hu, B.; Hu, C.; Zhu, F.; Liu, X.; Zhang, J.; Wang, B.; Xiang, H.; Cheng, Z.; Xiong, Y.; et al. Clinical Characteristics of 138 Hospitalized Patients with 2019 Novel Coronavirus-Infected Pneumonia in Wuhan, China. JAMA J. Am. Med. Assoc. 2020, 323, 1061. [CrossRef] [PubMed]

50. Wang, L.; Li, X.; Chen, H.; Yan, S.; Li, D.; Li, Y.; Gong, Z. Coronavirus disease 19 infection does not result in acute kidney injury: An analysis of 116 hospitalized patients from Wuhan, China. Am. J. Nephrol. 2020, 51, 343-348. [CrossRef]

51. Franzin, R.; Stasi, A.; Fiorentino, M.; Stallone, G.; Cantaluppi, V.; Gesualdo, L.; Castellano, G. Inflammaging and Complement System: A Link Between Acute Kidney Injury and Chronic Graft Damage. Front. Immunol. 2020, 11, 734. [CrossRef]

52. Guzzi, F.; Cirillo, L.; Roperto, R.M.; Romagnani, P.; Lazzeri, E. Molecular mechanisms of the acute kidney injury to chronic kidney disease transition: An updated view. Int. J. Mol. Sci. 2019, 20, 4941. [CrossRef] 
53. Chan, L.; Chaudhary, K.; Saha, A.; Chauhan, K.; Vaid, A.; Zhao, S.; Paranjpe, I.; Somani, S.; Richter, F.; Miotto, R.; et al. AKI in Hospitalized Patients with COVID-19. J. Am. Soc. Nephrol. 2020. [CrossRef]

54. Santos, R.A.S.; Ferreira, A.J.; Verano-Braga, T.; Bader, M. Angiotensin-converting enzyme 2, angiotensin-(1-7) and Mas: New players of the renin-angiotensin system. J. Endocrinol. 2012, 216, R1-R17. [CrossRef] [PubMed]

55. Aragão, D.S.; Cunha, T.S.; Arita, D.Y.; Andrade, M.C.C.; Fernandes, A.B.; Watanabe, I.K.M.; Mortara, R.A.; Casarini, D.E. Purification and characterization of angiotensin converting enzyme 2 (ACE2) from murine model of mesangial cell in culture. Int. J. Biol. Macromol. 2011, 49, 79-84. [CrossRef] [PubMed]

56. Hamming, I.; Timens, W.; Bulthuis, M.L.C.; Lely, A.T.; Navis, G.J.; van Goor, H. Tissue distribution of ACE2 protein, the functional receptor for SARS coronavirus. A first step in understanding SARS pathogenesis. J. Pathol. 2004, 203, 631-663. [CrossRef] [PubMed]

57. Li, N.; Zimpelmann, J.; Cheng, K.; Wilkins, J.A.; Burns, K.D. The role of angiotensin converting enzyme 2 in the generation of angiotensin 1-7 by rat proximal tubules. Am. J. Physiol. Ren. Physiol. 2005, 288, F353-F362. [CrossRef] [PubMed]

58. Soler, M.J.; Wysocki, J.; Batlle, D. ACE2 alterations in kidney disease. Nephrol. Dial. Transplant. 2013, 28, 2687-2697. [CrossRef] [PubMed]

59. Fang, F.; Liu, G.C.; Zhou, X.; Yang, S.; Reich, H.N.; Williams, V.; Hu, A.; Pan, J.; Konvalinka, A.; Oudit, G.Y.; et al. Loss of ACE2 Exacerbates Murine Renal Ischemia-Reperfusion Injury. PLoS ONE 2013, 8, e71433. [CrossRef] [PubMed]

60. Diao, B.; Wen, K.; Chen, J.; Liu, Y.; Yuan, Z.; Han, C.; Chen, J.; Pan, Y.; Chen, L.; Dan, Y.; et al. Diagnosis of Acute Respiratory Syndrome Coronavirus 2 Infection by Detection of Nucleocapsid Protein. medRxiv 2020. [CrossRef]

61. Ding, Y.; He, L.; Zhang, Q.; Huang, Z.; Che, X.; Hou, J.; Wang, H.; Shen, H.; Qiu, L.; Li, Z.; et al. Organ distribution of severe acute respiratory syndrome (SARS) associated coronavirus (SARS-CoV) in SARS patients: Implications for pathogenesis virus transmission pathways. J. Pathol. 2004, 203, 622-630. [CrossRef]

62. Cheng, Y.; Luo, R.; Wang, K.; Zhang, M.; Wang, Z.; Dong, L.; Li, J.; Yao, Y.; Ge, S.; Xu, G. Kidney disease is associated with in-hospital death of patients with COVID-19. Kidney Int. 2020. [CrossRef]

63. Kaneko, K.; Tsuji, S.; Kimata, T.; Kitao, T.; Yamanouchi, S.; Kato, S. Pathogenesis of childhood idiopathic nephrotic syndrome: A paradigm shift from T-cells to podocytes. World J. Pediatr. 2015, 11, 21-28. [CrossRef]

64. Santangelo, L.; Gigante, M.; Netti, G.S.; Diella, S.; Puteo, F.; Carbone, V.; Grandaliano, G.; Giordano, M.; Gesualdo, L. A novel SMARCAL1 mutation associated with a mild phenotype of Schimke immuno-osseous dysplasia (SIOD). BMC Nephrol. 2014, 15, 41. [CrossRef] [PubMed]

65. Gigante, M.; D'Altilia, M.; Montemurno, E.; Diella, S.; Bruno, F.; Netti, G.S.; Ranieri, E.; Stallone, G.; Infante, B.; Grandaliano, G.; et al. Branchio-Oto-Renal Syndrome (BOR) associated with focal glomerulosclerosis in a patient with a novel EYA1 splice site mutation. BMC Nephrol. 2013, 14, 60. [CrossRef] [PubMed]

66. Martinez-Rojas, M.A.; Vega-Vega, O.; Bobadilla, X.N.A. Is the kidney a target of SARS-CoV-2? Am. J. Physiol. Ren. Physiol. 2020. [CrossRef] [PubMed]

67. Königshausen, E.; Zierhut, U.M.; Ruetze, M.; Potthoff, S.A.; Stegbauer, J.; Woznowski, M.; Quack, I.; Rump, L.C.; Sellin, L. Angiotensin II increases glomerular permeability by $\beta$-arrestin mediated nephrin endocytosis. Sci. Rep. 2016, 6, 39513. [CrossRef] [PubMed]

68. Lucas, J.M.; True, L.; Hawley, S.; Matsumura, M.; Morrissey, C.; Vessella, R.; Nelson, P.S. The androgen-regulated type II serine protease TMPRSS2 is differentially expressed and mislocalized in prostate adenocarcinoma. J. Pathol. 2008, 215, 118-125. [CrossRef] [PubMed]

69. Rossi, G.M.; Delsante, M.; Pilato, F.P.; Gnetti, L.; Gabrielli, L.; Rossini, G.; Re, M.C.; Cenacchi, G.; Affanni, P.; Colucci, M.E.; et al. Kidney Biopsy Findings in a Critically Ill COVID-19 Patient with Dialysis-Dependent Acute Kidney Injury: A Case Against "SARS-CoV-2 Nephropathy". Kidney Int. Rep. 2020, 5, 1100-1110. [CrossRef]

70. Tay, M.Z.; Poh, C.M.; Rénia, L.; MacAry, P.A.; Ng, L.F.P. The trinity of COVID-19: Immunity, inflammation and intervention. Nat. Rev. Immunol. 2020, 20, 363-374. [CrossRef]

71. Shi, Y.; Wang, Y.; Shao, C.; Huang, J.; Gan, J.; Huang, X.; Bucci, E.; Piacentini, M.; Ippolito, G.; Melino, G. COVID-19 infection: The perspectives on immune responses. Cell Death Differ. 2020,27,1451-1454. [CrossRef]

72. Jia, H.P.; Look, D.C.; Shi, L.; Hickey, M.; Pewe, L.; Netland, J.; Farzan, M.; Wohlford-Lenane, C.; Perlman, S.; McCray, P.B. ACE2 Receptor Expression and Severe Acute Respiratory Syndrome Coronavirus Infection Depend on Differentiation of Human Airway Epithelia. J. Virol. 2005, 79, 14614-14621. [CrossRef] 
73. Kim, J.Y.; Ko, J.H.; Kim, Y.; Kim, Y.J.; Kim, J.M.; Chung, Y.S.; Kim, H.M.; Han, M.G.; Kim, S.Y.; Chin, B.S. Viral load kinetics of SARS-CoV-2 infection in first two patients in Korea. J. Korean Med. Sci. 2020. [CrossRef]

74. Zou, L.; Ruan, F.; Huang, M.; Liang, L.; Huang, H.; Hong, Z.; Yu, J.; Kang, M.; Song, Y.; Xia, J.; et al. SARS-CoV-2 viral load in upper respiratory specimens of infected patients. N. Engl. J. Med. 2020, 382, 1177-1179. [CrossRef] [PubMed]

75. Peiris, J.S.M.; Chu, C.M.; Cheng, V.C.C.; Chan, K.S.; Hung, I.F.N.; Poon, L.L.M.; Law, K.I.; Tang, B.S.F.; Hon, T.Y.W.; Chan, C.S.; et al. Clinical progression and viral load in a community outbreak of coronavirus-associated SARS pneumonia: A prospective study. Lancet 2003, 361, 1767-1772. [CrossRef]

76. Zhou, F.; Yu, T.; Du, R.; Fan, G.; Liu, Y.; Liu, Z.; Xiang, J.; Wang, Y.; Song, B.; Gu, X.; et al. Clinical course and risk factors for mortality of adult inpatients with COVID-19 in Wuhan, China: A retrospective cohort study. Lancet 2020, 395, 1054-1062. [CrossRef]

77. Li, G.; Fan, Y.; Lai, Y.; Han, T.; Li, Z.; Zhou, P.; Pan, P.; Wang, W.; Hu, D.; Liu, X.; et al. Coronavirus infections and immune responses. J. Med. Virol. 2020, 92, 424-432. [CrossRef]

78. Tufan, A.; Avanoğlu Güler, A.; Matucci-Cerinic, M. Covid-19, immune system response, hyperinflammation and repurposinantirheumatic drugs. Turk. J. Med. Sci. 2020, 50, 620-632. [CrossRef]

79. Li, H.; Liu, L.; Zhang, D.; Xu, J.; Dai, H.; Tang, N.; Su, X.; Cao, B. SARS-CoV-2 and viral sepsis: Observations and hypotheses. Lancet 2020. [CrossRef]

80. Remy, K.E.; Brakenridge, S.C.; Francois, B.; Daix, T.; Deutschman, C.S.; Monneret, G.; Jeannet, R.; Laterre, P.F.; Hotchkiss, R.S.; Moldawer, L.L. Immunotherapies for COVID-19: Lessons learned from sepsis. Lancet Respir. Med. 2020, 8, 946-949. [CrossRef]

81. Qin, C.; Zhou, L.; Hu, Z.; Zhang, S.; Yang, S.; Tao, Y.; Xie, C.; Ma, K.; Shang, K.; Wang, W.; et al. Dysregulation of immune response in patients with COVID-19 in Wuhan, China. Clin. Infect. Dis. 2020. [CrossRef]

82. Yang, Y.; Shen, C.; Li, J.; Yuan, J.; Yang, M.; Wang, F.; Li, G.; Li, Y.; Xing, L.; Peng, L.; et al. Exuberant elevation of IP-10, MCP-3 and IL-1ra during SARS-CoV-2 infection is associated with disease severity and fatal outcome. medRxiv 2020. [CrossRef]

83. Chen, L.; Liu, H.G.; Liu, W.; Liu, J.; Liu, K.; Shang, J.; Deng, Y.; Wei, S. Analysis of clinical features of 29 patients with 2019 novel coronavirus pneumonia. Zhonghua Jie He He Hu Xi Za Zhi 2020, 43, E005.

84. Wang, W.; He, J.; Lie, P.; Huang, L.; Wu, S.; Lin, Y.; Liu, X. The definition and risks of cytokine release syndrome-like in 11 COVID-19-infected pneumonia critically ill patients: Disease characteristics and retrospective analysis. medRxiv 2020. [CrossRef]

85. Su, H.; Lei, C.T.; Zhang, C. Interleukin-6 signaling pathway and its role in kidney disease: An update. Front. Immunol. 2017, 8, 405. [CrossRef]

86. Husain-Syed, F.; Slutsky, A.S.; Ronco, C. Lung-kidney cross-talk in the critically ill patient. Am. J. Respir. Crit. Care Med. 2016, 194, 402-414. [CrossRef]

87. Ronco, C.; Reis, T.; Husain-Syed, F. Management of acute kidney injury in patients with COVID-19. Lancet Respir. Med. 2020. [CrossRef]

88. Gautier-Vargas, G.; Baldacini, C.; Benotmane, I.; Keller, N.; Perrin, P.; Moulin, B.; Caillard, S. Rapid resolution of cytokine release syndrome and favorable clinical course of severe COVID-19 in a kidney transplant recipient treated with tocilizumab. Kidney Int. 2020, 98, 508-509. [CrossRef] [PubMed]

89. Hu, Z.-J.; Xu, J.; Yin, J.-M.; Li, L.; Hou, W.; Zhang, L.-L.; Zhou, Z.; Yu, Y.-Z.; Li, H.-J.; Feng, Y.-M.; et al. Lower Circulating Interferon-Gamma Is a Risk Factor for Lung Fibrosis in COVID-19 Patients. Front. Immunol. 2020, 11, 2348. [CrossRef] [PubMed]

90. Lagunas-Rangel, F.A.; Chávez-Valencia, V. High IL-6/IFN- $\gamma$ ratio could be associated with severe disease in COVID-19 patients. J. Med. Virol. 2020. [CrossRef]

91. Bajwa, A.; Huang, L.; Kurmaeva, E.; Ye, H.; Dondeti, K.R.; Chroscicki, P.; Foley, L.S.; Balogun, Z.A.; Alexander, K.J.; Park, H.; et al. Sphingosine kinase 2 deficiency attenuates kidney fibrosis via IFN- $\gamma$. J. Am. Soc. Nephrol. 2016, 28, 1145-1161. [CrossRef]

92. Poosti, F.; Bansal, R.; Yazdani, S.; Prakash, J.; Beljaars, L.; van den Born, J.; de Borst, M.H.; van Goor, H.; Hillebrands, J.L.; Poelstra, K. Interferon gamma peptidomimetic targeted to interstitial myofibroblasts attenuates renal fibrosis after unilateral ureteral obstruction in mice. Oncotarget 2016, 7, 54240-54252. [CrossRef]

93. Castellano, G.; Woltman, A.M.; Schlagwein, N.; Xu, W.; Schena, F.P.; Daha, M.R.; van Kooten, C. Immune modulation of human dendritic cells by complement. Eur. J. Immunol. 2007, 37, 2803-2811. [CrossRef] 
94. Castellano, G.; Cappiello, V.; Fiore, N.; Pontrelli, P.; Gesualdo, L.; Schena, F.P.; Montinaro, V. CD40 ligand increases complement C3 secretion by proximal tubular epithelial cells. J. Am. Soc. Nephrol. 2005, 16, 2003-2011. [CrossRef]

95. Loverre, A.; Divella, C.; Castellano, G.; Tataranni, T.; Zaza, G.; Rossini, M.; Ditonno, P.; Battaglia, M.; Palazzo, S.; Gigante, M.; et al. T helper 1, 2 and 17 cell subsets in renal transplant patients with delayed graft function. Transpl. Int. 2011, 24, 233-242. [CrossRef]

96. Castellano, G.; Cafiero, C.; Divella, C.; Sallustio, F.; Gigante, M.; Pontrelli, P.; de Palma, G.; Rossini, M.; Grandaliano, G.; Gesualdo, L. Local synthesis of interferon-alpha in lupus nephritis is associated with type I interferons signature and LMP7 induction in renal tubular epithelial cells. Arthritis Res. Ther. 2015, 17, 1-13. [CrossRef] [PubMed]

97. Law, B.M.P.; Wilkinson, R.; Wang, X.; Kildey, K.; Lindner, M.; Rist, M.J.; Beagley, K.; Healy, H.; Kassianos, A.J. Interferon- $\gamma$ production by tubulointerstitial human CD56bright natural killer cells contributes to renal fibrosis and chronic kidney disease progression. Kidney Int. 2017, 92, 79-88. [CrossRef] [PubMed]

98. Ronco, C.; Reis, T. Kidney involvement in COVID-19 and rationale for extracorporeal therapies. Nat. Rev. Nephrol. 2020, 16, 308-310. [CrossRef] [PubMed]

99. Izzedine, H.; Jhaveri, K.D. Acute kidney injury in patients with COVID-19: An update on the pathophysiology. Nephrol. Dial. Transplant. 2020. [CrossRef] [PubMed]

100. Scrascia, G.; Rotunno, C.; Simone, S.; Montemurno, E.; Amorese, L.; de Palo, M.; Castellano, G.; Pertosa, G.B.; Gesualdo, L.; Paparella, D. Acute kidney injury in high-risk cardiac surgery patients: Roles of inflammation and coagulation. J. Cardiovasc. Med. 2017, 18, 359-365. [CrossRef]

101. Zhou, Y.; Fu, B.; Zheng, X.; Wang, D.; Zhao, C.; Qi, Y.; Sun, R.; Tian, Z.; Xu, X.; Wei, H. Pathogenic T cells and inflammatory monocytes incite inflammatory storm in severe COVID-19 patients. Natl. Sci. Rev. 2020, 7, 998-1002. [CrossRef]

102. Zheng, M.; Gao, Y.; Wang, G.; Song, G.; Liu, S.; Sun, D.; Xu, Y.; Tian, Z. Functional exhaustion of antiviral lymphocytes in COVID-19 patients. Cell. Mol. Immunol. 2020, 17, 533-535. [CrossRef]

103. Croxford, A.L.; Lanzinger, M.; Hartmann, F.J.; Schreiner, B.; Mair, F.; Pelczar, P.; Clausen, B.E.; Jung, S.; Greter, M.; Becher, B. The Cytokine GM-CSF Drives the Inflammatory Signature of CCR2+Monocytes and Licenses Autoimmunity. Immunity 2015, 43, 502-514. [CrossRef]

104. Dong Kim, K.; Zhao, J.; Auh, S.; Yang, X.; Du, P.; Tang, H.; Fu, Y.X. Adaptive immune cells temper initial innate responses. Nat. Med. 2007, 13, 1248-1252. [CrossRef] [PubMed]

105. Palm, N.W.; Medzhitov, R. Not so fast: Adaptive suppression of innate immunity. Nat. Med. 2007, 13, 1142-1144. [CrossRef] [PubMed]

106. Liu, J.; Li, S.; Liu, J.; Liang, B.; Wang, X.; Wang, H.; Li, W.; Tong, Q.; Yi, J.; Zhao, L.; et al. Longitudinal characteristics of lymphocyte responses and cytokine profiles in the peripheral blood of SARS-CoV-2 infected patients. EBioMedicine 2020. [CrossRef] [PubMed]

107. Sakaguchi, S.; Yamaguchi, T.; Nomura, T.; Ono, M. Regulatory T Cells and Immune Tolerance. Cell 2008. [CrossRef] [PubMed]

108. Sakaguchi, S.; Miyara, M.; Costantino, C.M.; Hafler, D.A. FOXP3+regulatory T cells in the human immune system. Nat. Rev. Immunol. 2010, 10, 490-500. [CrossRef]

109. Wan, S.; Yi, Q.; Fan, S.; Lv, J.; Zhang, X.; Guo, L.; Lang, C.; Xiao, Q.; Xiao, K.; Yi, Z.; et al. Characteristics of lymphocyte subsets and cytokines in peripheral blood of 123 hospitalized patients with 2019 novel coronavirus pneumonia (NCP). medRxiv 2020. [CrossRef]

110. Sallusto, F.; Lenig, D.; Förster, R.; Lipp, M.; Lanzavecchia, A. Two subsets of memory T lymphocytes with distinct homing potentials and effector functions. Nature 1999, 401, 708-712. [CrossRef]

111. Wang, F.; Nie, J.; Wang, H.; Zhao, Q.; Xiong, Y.; Deng, L.; Song, S.; Ma, Z.; Mo, P.; Zhang, Y. Characteristics of Peripheral Lymphocyte Subset Alteration in COVID-19 Pneumonia. J. Infect. Dis. 2020, 221, 1762-1769. [CrossRef]

112. Yoshikawa, T.; Hill, T.; Li, K.; Peters, C.J.; Tseng, C.-T.K. Severe Acute Respiratory Syndrome (SARS) Coronavirus-Induced Lung Epithelial Cytokines Exacerbate SARS Pathogenesis by Modulating Intrinsic Functions of Monocyte-Derived Macrophages and Dendritic Cells. J. Virol. 2009, 83, 3039-3048. [CrossRef]

113. Xu, Z.; Shi, L.; Wang, Y.; Zhang, J.; Huang, L.; Zhang, C.; Liu, S.; Zhao, P.; Liu, H.; Zhu, L.; et al. Pathological findings of COVID-19 associated with acute respiratory distress syndrome. Lancet Respir. Med. 2020, 8, 420-422. [CrossRef] 
114. Tian, S.; Hu, W.; Niu, L.; Liu, H.; Xu, H.; Xiao, S.Y. Pulmonary Pathology of Early-Phase 2019 Novel Coronavirus (COVID-19) Pneumonia in Two Patients with Lung Cancer. J. Thorac. Oncol. 2020, 15, 700-704. [CrossRef] [PubMed]

115. Schmouder, R.L.; Strieter, R.M.; Wiggins, R.C.; Chensue, S.W.; Kunkel, S.L. In vitro and in vivo interleukin-8 production in human renal cortical epithelia. Kidney Int. 1992, 41, 191-198. [CrossRef] [PubMed]

116. Gerritsma, J.S.J.; Hiemstra, P.S.; Gerritsen, A.F.; Prodjosudjadi, W.; Verweij, C.L.; van Es, L.A.; Daha, M.R. Regulation and production of IL-8 by human proximal tubular epithelial cells in vitro. Clin. Exp. Immunol. 1996, 103, 289-294. [CrossRef]

117. Tang, S.; Leung, J.C.K.; Abe, K.; Chan, K.W.; Chan, L.Y.Y.; Chan, T.M.; Lai, K.N. Albumin stimulates interleukin-8 expression in proximal tubular epithelial cells in vitro and in vivo. J. Clin. Investig. 2003, 111, 515-527. [CrossRef]

118. Zhou, Z.; Ren, L.; Zhang, L.; Zhong, J.; Xiao, Y.; Jia, Z.; Guo, L.; Yang, J.; Wang, C.; Jiang, S.; et al. Overly Exuberant Innate Immune Response to SARS-CoV-2 Infection. SSRN Electron. J. 2020. [CrossRef]

119. Liao, M.; Liu, Y.; Yuan, J.; Wen, Y.; Xu, G.; Zhao, J.; Chen, L.; Li, J.; Wang, X.; Wang, F.; et al. The landscape of lung bronchoalveolar immune cells in COVID-19 revealed by single-cell RNA sequencing. medRxiv 2020. [CrossRef]

120. Ramachandran, P.; Dobie, R.; Wilson-Kanamori, J.R.; Dora, E.F.; Henderson, B.E.P.; Luu, N.T.; Portman, J.R.; Matchett, K.P.; Brice, M.; Marwick, J.A.; et al. Resolving the fibrotic niche of human liver cirrhosis at single-cell level. Nature 2019, 575, 512-518. [CrossRef]

121. Merad, M.; Martin, J.C. Pathological inflammation in patients with COVID-19: A key role for monocytes and macrophages. Nat. Rev. Immunol. 2020, 20, 355-362. [CrossRef]

122. Zhang, D.; Guo, R.; Lei, L.; Liu, H.; Wang, Y.; Wang, Y.; Dai, T.; Zhang, T.; Lai, Y.; Wang, J.; et al. COVID-19 infection induces readily detectable morphological and inflammation-related phenotypic changes in peripheral blood monocytes, the severity of which correlate with patient outcome. medRxiv 2020. [CrossRef]

123. Quinti, I.; Lougaris, V.; Milito, C.; Cinetto, F.; Pecoraro, A.; Mezzaroma, I.; Mastroianni, C.M.; Turriziani, O.; Bondioni, M.P.; Filippini, M.; et al. A possible role for B cells in COVID-19? Lesson from patients with agammaglobulinemia. J. Allergy Clin. Immunol. 2020, 146, 211-213. [CrossRef]

124. Arkatkar, T.; Du, S.W.; Jacobs, H.M.; Dam, E.M.; Hou, B.; Buckner, J.H.; Rawlings, D.J.; Jackson, S.W. B cell-derived IL-6 initiates spontaneous germinal center formation during systemic autoimmunity. J. Exp. Med. 2017, 214, 3207-3217. [CrossRef] [PubMed]

125. Pecoraro, A.; Crescenzi, L.; Galdiero, M.R.; Marone, G.; Rivellese, F.; Rossi, F.W.; de Paulis, A.; Genovese, A.; Spadaro, G. Immunosuppressive therapy with rituximab in common variable immunodeficiency. Clin. Mol. Allergy 2019, 17, 1-11. [CrossRef] [PubMed]

126. Noris, M.; Benigni, A.; Remuzzi, G. The case of complement activation in COVID-19 multiorgan impact. Kidney Int. 2020, 98, 314-322. [CrossRef] [PubMed]

127. Mayilyan, K.R.; Kang, Y.H.; Dodds, A.W.; Sim, R.B. The Complement System in Innate Immunity. In Innate Immunity of Plants, Animals, and Humans; Springer: Berlin, Germany, 2008.

128. Noris, M.; Remuzzi, G. Overview of complement activation and regulation. Semin. Nephrol. 2013, 33, 479-492. [CrossRef] [PubMed]

129. Simone, S.; Rascio, F.; Castellano, G.; Divella, C.; Chieti, A.; Ditonno, P.; Battaglia, M.; Crovace, A.; Staffieri, F.; Oortwijn, B.; et al. Complement-dependent NADPH oxidase enzyme activation in renal ischemia/reperfusion injury. Free Radic. Biol. Med. 2014, 74, 263-273. [CrossRef] [PubMed]

130. Gao, T.; Hu, M.; Zhang, X.; Li, H.; Zhu, L.; Liu, H.; Dong, Q.; Zhang, Z.; Wang, Z.; Hu, Y.; et al. Highly pathogenic coronavirus $\mathrm{N}$ protein aggravates lung injury by MASP-2-mediated complement over-activation. medRxiv 2020. [CrossRef]

131. Yang, Y.H.; Huang, Y.H.; Chuang, Y.H.; Peng, C.M.; Wang, L.C.; Lin, Y.T.; Chiang, B.L. Autoantibodies against human epithelial cells and endothelial cells after severe acute respiratory syndrome (SARS)-associated coronavirus infection. J. Med. Virol. 2005, 77, 1-7. [CrossRef]

132. Gralinski, L.E.; Sheahan, T.P.; Morrison, T.E.; Menachery, V.D.; Jensen, K.; Leist, S.R.; Whitmore, A.; Heise, M.T.; Baric, R.S. Complement activation contributes to severe acute respiratory syndrome coronavirus pathogenesis. MBio 2018, 9, e01753-18. [CrossRef]

133. Giordano, P.; Netti, G.S.; Santangelo, L.; Castellano, G.; Carbone, V.; Torres, D.D.; Martino, M.; Sesta, M.; Di Cuonzo, F.; Resta, M.C.; et al. A pediatric neurologic assessment score may drive the 
eculizumab-based treatment of Escherichia coli-related hemolytic uremic syndrome with neurological involvement. Pediatr. Nephrol. 2019, 34, 517-527. [CrossRef]

134. Netti, G.S.; Santangelo, L.; Paulucci, L.; Piscopo, G.; Torres, D.D.; Carbone, V.; Giordano, P.; Spadaccino, F.; Castellano, G.; Stallone, G.; et al. Low C3 Serum Levels Predict Severe Forms of STEC-HUS with Neurologic Involvement. Front. Med. 2020, 7, 357. [CrossRef]

135. Tang, D.; Comish, P.; Kang, R. The hallmarks of COVID-19 disease. PLoS Pathog. 2020, 16, e1008536. [CrossRef] [PubMed]

136. Boisramé-Helms, J.; Kremer, H.; Schini-Kerth, V.; Meziani, F. Endothelial dysfunction in sepsis. Curr. Vasc. Pharmacol. 2013, 11, 150-156. [PubMed]

137. Castellano, G.; Stasi, A.; Intini, A.; Gigante, M.; Di Palma, A.M.; Divella, C.; Netti, G.S.; Prattichizzo, C.; Pontrelli, P.; Crovace, A.; et al. Endothelial dysfunction and renal fibrosis in endotoxemia-induced oliguric kidney injury: Possible role of LPS-binding protein. Crit. Care 2014, 18, 520. [CrossRef] [PubMed]

138. Netti, G.S.; Sangregorio, F.; Spadaccino, F.; Staffieri, F.; Crovace, A.; Infante, B.; Maiorano, A.; Godeas, G.; Castellano, G.; Di Palma, A.M.; et al. LPS removal reduces CD80-mediated albuminuria in critically ill patients with gram-negative sepsis. Am. J. Physiol. Ren. Physiol. 2019, 316, F723-F731. [CrossRef]

139. Castellano, G.; Stasi, A.; Franzin, R.; Sallustio, F.; Divella, C.; Spinelli, A.; Netti, G.S.; Fiaccadori, E.; Cantaluppi, V.; Crovace, A.; et al. LPS-binding protein modulates acute renal fibrosis by inducing pericyte-to-myofibroblast trans-differentiation through TLR-4 signaling. Int. J. Mol. Sci. 2019, 20, 3682. [CrossRef]

140. Varga, Z.; Flammer, A.J.; Steiger, P.; Haberecker, M.; Andermatt, R.; Zinkernagel, A.S.; Mehra, M.R.; Schuepbach, R.A.; Ruschitzka, F.; Moch, H. Endothelial cell infection and endotheliitis in COVID-19. Lancet 2020, 395, 1417-1418. [CrossRef]

141. Uzunova, K.; Filipova, E.; Pavlova, V.; Vekov, T. Insights into antiviral mechanisms of remdesivir, lopinavir/ritonavir and chloroquine/hydroxychloroquine affecting the new SARS-CoV-2. Biomed. Pharmacother. 2020. [CrossRef]

142. Markiewski, M.M.; DeAngelis, R.A.; Lambris, J.D. Complexity of complement activation in sepsis. J. Cell. Mol. Med. 2008, 12, 2245-2254. [CrossRef]

143. Castellano, G.; Franzin, R.; Sallustio, F.; Stasi, A.; Banelli, B.; Romani, M.; de Palma, G.; Lucarelli, G.; Divella, C.; Battaglia, M.; et al. Complement component C5a induces aberrant epigenetic modifications in renal tubular epithelial cells accelerating senescence by Wnt4/ßcatenin signaling after ischemia/reperfusion injury. Aging 2019. [CrossRef]

144. Castellano, G.; Franzin, R.; Stasi, A.; Divella, C.; Sallustio, F.; Pontrelli, P.; Lucarelli, G.; Battaglia, M.; Staffieri, F.; Crovace, A.; et al. Complement activation during ischemia/reperfusion injury induces pericyte-to-myofibroblast transdifferentiation regulating peritubular capillary Lumen Reduction Through pERK Signaling. Front. Immunol. 2018, 9, 1002. [CrossRef]

145. Curci, C.; Castellano, G.; Stasi, A.; Divella, C.; Loverre, A.; Gigante, M.; Simone, S.; Cariello, M.; Montinaro, V.; Lucarelli, G.; et al. Endothelial-to-mesenchymal transition and renal fibrosis in ischaemia/reperfusion injury are mediated by complement anaphylatoxins and Akt pathway. Nephrol. Dial. Transpl. 2014, 29, 799-808. [CrossRef] [PubMed]

146. Castellano, G.; Intini, A.; Stasi, A.; Divella, C.; Gigante, M.; Pontrelli, P.; Franzin, R.; Accetturo, M.; Zito, A.; Fiorentino, M.; et al. Complement Modulation of Anti-Aging Factor Klotho in Ischemia/Reperfusion Injury and Delayed Graft Function. Am. J. Transpl. 2016, 16, 325-333. [CrossRef] [PubMed]

147. Wang, K.; Chen, W.; Zhou, Y.-S.; Lian, J.-Q.; Zhang, Z.; Du, P.; Gong, L.; Zhang, Y.; Cui, H.-Y.; Geng, J.-J.; et al. SARS-CoV-2 invades host cells via a novel route: CD147-spike protein. bioRxiv 2020. [CrossRef]

148. Kuppalli, K.; Rasmussen, A.L. A glimpse into the eye of the COVID-19 cytokine storm. EBioMedicine 2020, 55, 102789. [CrossRef] [PubMed]

149. Batlle, D.; Soler, M.J.; Sparks, M.A.; Hiremath, S.; South, A.M.; Welling, P.A.; Swaminathan, S.; Sparks, M.A.; Hiremath, S.; Batlle, D.; et al. Acute kidney injury in COVID-19: Emerging evidence of a distinct pathophysiology. J. Am. Soc. Nephrol. 2020, 31, 1380-1383. [CrossRef] [PubMed]

150. Sun, X.; Wang, T.; Cai, D.; Hu, Z.; Chen, J.; Liao, H.; Zhi, L.; Wei, H.; Zhang, Z.; Qiu, Y.; et al. Cytokine storm intervention in the early stages of COVID-19 pneumonia. Cytokine Growth Factor Rev. 2020, 53, 38-42. [CrossRef] 
151. Joannidis, M.; Forni, L.G.; Klein, S.J.; Honore, P.M.; Kashani, K.; Ostermann, M.; Prowle, J.; Bagshaw, S.M.; Cantaluppi, V.; Darmon, M.; et al. Lung-kidney interactions in critically ill patients: Consensus report of the Acute Disease Quality Initiative (ADQI) 21 Workgroup. Intensive Care Med. 2020, 46, 654-672. [CrossRef]

152. Husain-Syed, F.; Ricci, Z.; Brodie, D.; Vincent, J.L.; Ranieri, V.M.; Slutsky, A.S.; Taccone, F.S.; Gattinoni, L.; Ronco, C. Extracorporeal organ support (ECOS) in critical illness and acute kidney injury: From native to artificial organ crosstalk. Intensive Care Med. 2018, 44, 1447-1459. [CrossRef]

153. Goldfarb, D.S.; Benstein, J.A.; Zhdanova, O.; Hammer, E.; Block, C.A.; Caplin, N.J.; Thompson, N.; Charytan, D.M. Impending shortages of kidney replacement therapy for covid-19 patients. Clin. J. Am. Soc. Nephrol. 2020, 15, 880-882. [CrossRef]

154. Sourial, M.Y.; Sourial, M.H.; Dalsan, R.; Graham, J.; Ross, M.; Chen, W.; Golestaneh, L. Urgent Peritoneal Dialysis in Patients With COVID-19 and Acute Kidney Injury: A Single-Center Experience in a Time of Crisis in the United States. Am. J. Kidney Dis. 2020, 76, 401-406. [CrossRef]

155. Vigiola Cruz, M.; Bellorin, O.; Srivatana, V.; Afaneh, C. Safety and Efficacy of Bedside Peritoneal Dialysis Catheter Placement in the COVID-19 Era: Initial Experience at a New York City Hospital. World J. Surg. 2020. [CrossRef]

156. Yao, J.; Li, S.; Zhou, L.; Luo, L.; Yuan, L.; Duan, Z.; Xu, J.; Chen, Y. Therapeutic effect of double plasma molecular adsorption system and sequential half-dose plasma exchange in patients with HBV-related acute-on-chronic liver failure. J. Clin. Apher. 2019, 34, 392-398. [CrossRef] [PubMed]

157. Huang, Z.; Wang, S.R.; Su, W.; Liu, J.Y. Removal of humoral mediators and the effect on the survival of septic patients by hemoperfusion with neutral microporous resin column. Ther. Apher. Dial. 2010, 14, 596-602. [CrossRef] [PubMed]

158. Ronco, C.; Bagshaw, S.M.; Bellomo, R.; Clark, W.R.; Husain-Syed, F.; Kellum, J.A.; Ricci, Z.; Rimmelé, T.; Reis, T.; Ostermann, M. Extracorporeal blood purification and organ support in the critically ill patient during covid-19 pandemic: Expert review and recommendation. Blood Purif. 2020, 1-11. [CrossRef] [PubMed]

159. Ronco, C.; Tetta, C.; Mariano, F.; Wratten, M.L.; Bonello, M.; Bordoni, V.; Cardona, X.; Inguaggiato, P.; Pilotto, L.; D'Intini, V.; et al. Interpreting the mechanisms of continuous renal replacement therapy in sepsis: The peak concentration hypothesis. Artif. Organs 2003, 27, 792-801. [CrossRef]

160. Asgharpour, M.; Mehdinezhad, H.; Bayani, M.; Zavareh, M.S.H.; Hamidi, S.H.; Akbari, R.; Ghadimi, R.; Bijani, A.; Mouodi, S. Effectiveness of extracorporeal blood purification (hemoadsorption) in patients with severe coronavirus disease 2019 (COVID-19). BMC Nephrol. 2020, 21, 356. [CrossRef]

161. Dastan, F.; Saffaei, A.; Mortazavi, S.M.; Jamaati, H.; Adnani, N.; Samiee Roudi, S.; Kiani, A.; Abedini, A.; Hashemian, S.M.R. Continues renal replacement therapy (CRRT) with disposable hemoperfusion cartridge: A promising option for severe COVID-19. J. Glob. Antimicrob. Resist. 2020, 21, 340-341. [CrossRef]

162. Kellum, J.A.; Pike, F.; Yealy, D.M.; Huang, D.T.; Shapiro, N.I.; Angus, D.C. Relationship between Alternative Resuscitation Strategies, Host Response and Injury Biomarkers, and Outcome in Septic Shock: Analysis of the Protocol-Based Care for Early Septic Shock Study. J. Emerg. Med. 2017, 52, 906. [CrossRef]

163. Wilbers, T.J.; Koning, M.V. Renal replacement therapy in critically ill patients with COVID-19: A retrospective study investigating mortality, renal recovery and filter lifetime. J. Crit. Care 2020, 60, 103-105. [CrossRef]

164. Yang, Y.; Shi, J.; Ge, S.; Guo, S.; Xing, X.; Wang, Y.; Cheng, A.; Liu, Q.; Li, J.; Ning, Y.; et al. Association between Prolonged Intermittent Renal Replacement Therapy and All-Cause Mortality in COVID-19 Patients Undergoing Invasive Mechanical Ventilation: A Retrospective Cohort Study. medRxiv 2020. [CrossRef]

Publisher's Note: MDPI stays neutral with regard to jurisdictional claims in published maps and institutional affiliations.

(C) 2020 by the authors. Licensee MDPI, Basel, Switzerland. This article is an open access article distributed under the terms and conditions of the Creative Commons Attribution (CC BY) license (http://creativecommons.org/licenses/by/4.0/). 